\title{
Distribution of $\mathrm{Ni}$, Co, Precious, and Platinum Group Metals in Copper Making Process
}

\author{
DMITRY SUKHOMLINOV (1), LASSI KLEMETTINEN (D), KATRI AVARMAA (1), \\ HUGH O'BRIEN, PEKKA TASKINEN (1), and ARI JOKILAAKSO (D)
}

The distribution coefficients of $\mathrm{Ni}, \mathrm{Co}, \mathrm{Ag}, \mathrm{Au}, \mathrm{Pt}$, and $\mathrm{Pd}$ between molten copper and silica-saturated iron silicate slags $\left(\mathrm{L}_{\mathrm{Me}}^{\mathrm{Cu}}\right)$ were measured experimentally. The distribution behaviors were studied under typical conditions of copper converting and fire refining, i.e., from $1250{ }^{\circ} \mathrm{C}$ to $1350{ }^{\circ} \mathrm{C}$, and from $10^{-8}$ to $10^{-4}$ atm oxygen partial pressure. The coefficients were determined as the ratios of the trace element weight concentrations measured in situ, directly from the equilibrated metal and slag phases. For the quantitative elemental analysis of the phases, state-of-the-art analytic techniques, including electron probe microanalysis and laser ablation-inductively coupled plasma-mass spectrometry, were employed. The distribution coefficients $\mathrm{L}_{\mathrm{Me}}^{\mathrm{Cu}}$ determined can be arranged in the following order: $\mathrm{Pt}>\mathrm{Au}>\mathrm{Pd}>>\mathrm{Ag}>$ $(\mathrm{Cu})>\mathrm{Ni}>\mathrm{Co}>(\mathrm{Fe})$.

https://doi.org/10.1007/s11663-019-01576-2

(C) The Author(s) 2019

\section{INTRODUCTION}

OUR society requires a continuous, ever-increasing supply of metals to maintain modern levels of living. Growing metal demand with decreasing natural resources requires dramatic increases in metal recycling, achievable only with the ability to process new complex feed materials efficiently. For metals' production from these complex materials, accurate thermodynamic and phase equilibrium data are essential, especially for the minor elements in the base metals processing. Sustainability and resource efficiency concepts are driving to develop integrated, cleaner processes, which fully utilize renewable resources, i.e., metals recycling, with the least environmental impact. In particular, the aim is to build an industrial circular economy model, which is "a regenerative system in which resource input and waste, emission, and energy leakage are minimized by slowing, closing, and narrowing material and energy loops". ${ }^{[1]}$

Metal wastes, such as various end-of-life (EoL) electrical and electronic equipment, have a particularly high value as secondary sources of metals. The concentrations of valuable elements in e-wastes (WEEE) are

DMITRY SUKHOMLINOV, LASSI KLEMETTINEN, KATRI AVARMAA, PEKKA TASKINEN, and ARI JOKILAAKSO are with the Department of Chemical and Metallurgical Engineering, School of Chemical Engineering, Aalto University, P.O. Box 16100, Kemistintie 1, 00076Espoo, Finland. Contact e-mail: pekka.taskinen@aalto.fi HUGH O'BRIEN is with the Geological Survey of Finland, Betonimiehenkuja 4, 02150, Espoo, Finland.

Manuscript submitted December 19, 2018.

Article published online April 22, 2019. higher than in sulfidic copper ores. ${ }^{[2]}$ The best practices for processing copper-bearing wastes and e-scrap worldwide are the black copper smelting route ${ }^{[3,4]}$ and the primary matte smelting copper making route, integrated with secondary raw materials utilization. ${ }^{[5]} \mathrm{A}$ fraction of such wastes is processed through the black copper smelting route, where low-grade scrap is typically treated in top-submerged lance ${ }^{[6,7]}$ and Kaldo furnaces under consecutive reducing and oxidizing conditions. ${ }^{[2]}$ Alternatively, high-grade copper scrap can be charged directly to copper converter in the primary copper making route.

Efficient processing of complex copper sulfide concentrates and scrap requires thermodynamic data for the separation of impurities under the copper-making conditions. Present industrial practices, especially for secondary materials processing, are not optimized. One of the main reasons is the scarcity of the available thermodynamic data for minor elements. Moreover, the elements of e-scrap have variable favorable conditions for their pyrometallurgical recovery, i.e., the combination of temperature, oxygen potential, and slag composition.

\section{A. Context}

Rapidly changing technologies and consequently a short life span cause an increasing rate of EoL equipment generation, faster than any other type of waste. ${ }^{[8,9]}$ Due to the increasing volume of WEEE and more strict environmental regulations, the traditional way of e-waste handling, i.e., burning in incinerators, disposing in landfills or exporting abroad for disposal, 
is no longer an option. ${ }^{[10]}$ Also, due to advancement of technology, electronic products are getting more demanding for their subsequent recycling, as e-waste currently may contain up to 50 elements including precious (PM) and hazardous metals. ${ }^{[11]}$ For instance, PMs used as contact materials are essential components of electronics, while platinum group metals (PGMs) are utilized in relays, switches, catalysts, and high-temperature applications. ${ }^{[2]}$

Most of the value in scrap produced from, e.g., EoL cell phones and printed circuit boards (PCBs) is associated with PMs, rather than copper. ${ }^{[2]}$ For instance, cell phones contain up to 20 to 120 ppmw of $\mathrm{Ag}, \mathrm{Au}, \mathrm{Pd}$, and $\mathrm{Pt},{ }^{[12]}$ while $\mathrm{PCBs}$, which are essential parts of electronics, contain as much as 0.1 to $0.2 \mathrm{wt}$ pct $\mathrm{Ag}$ and

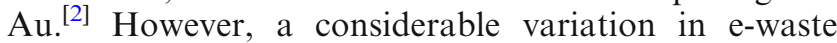
composition has been reported depending on its age, origin, manufacturer, and, e.g., concentrations of non-ferrous metals and PMs have been gradually decreasing in WEEE over the past few decades. ${ }^{[2]}$

Crude copper generated in the processing acts as a collector for the noble metals, which are separated and refined in the subsequent stages. Thus, it is beneficial to know precisely the operational conditions favorable for higher recovery rates of these metals. Furthermore, the credits from these metals produced as by-products improve the economics of copper making plants, while decreased levels of the harmful elements in discarded slags mitigates environmental hazards.

This study aims at providing new experimental data for facilitating an increase in the efficiencies of raw materials handling and saving mineral resources, as well as the use of WEEE in primary copper processing circuits. The distribution coefficients of elements between metallic copper and slag determine the levels of harmful impurities in copper and losses of valuable elements to slag. Therefore, we focused on valuable metal recovery in the primary copper making by accurate determination of the distribution coefficients. The focus was on the behavior of $\mathrm{Ni}, \mathrm{Co}, \mathrm{Ag}, \mathrm{Au}, \mathrm{Pt}$, and $\mathrm{Pd}$ in copper converting and fire refining, and distributions of the elements between metallic copper and iron silicate slag within temperature and oxygen partial pressure ranges of interest. The study is an extension of our results reported earlier. ${ }^{[13]}$

\section{B. Previous Studies}

Mackey et al. ${ }^{[14-16]}$ investigated the Noranda process and determined distribution ratios for various trace elements among the phases present in the reactor during pilot experiments. The operational conditions were $1250^{\circ} \mathrm{C}, 0.21$ to $0.3 \mathrm{~atm} p_{\mathrm{O}_{2}}$ for the gas blow and $\mathrm{Fe} /$ $\mathrm{SiO}_{2}$ ratios of 1.4 to 1.9 . While the values reported are useful, they do not necessarily represent the equilibrium distribution coefficients, because industrial conditions are always dynamic and compositional gradients exist within the phases. For $\mathrm{Co}, \mathrm{Ni}, \mathrm{Ag}$, and $\mathrm{Au}$, the distribution coefficient $\mathrm{L}_{\mathrm{Me}}^{\mathrm{Cu} / \mathrm{s}}$ values reported were 0.3 , $0.6,30$, and 300, respectively.
Takeda et al. ${ }^{[17]}$ reported distributions of various trace elements between copper and $\mathrm{Fe}-\mathrm{O}-\mathrm{CaO}$ and $\mathrm{Fe}-\mathrm{O}-\mathrm{SiO}_{2}$ slags over a wide range of oxygen partial pressure at $1250{ }^{\circ} \mathrm{C}$. The suggested forms of dissolved species in slag were $\mathrm{CuO}_{0.5}, \mathrm{AgO}_{0.5}$, and $\mathrm{CoO}$, while for nickel an intermediate slope between $\mathrm{NiO}$ and $\mathrm{NiO}_{0.5}$ was reported. Insignificant differences in the distribution behaviors of $\mathrm{Co}$ and $\mathrm{Ni}$ between the slags were reported. The distribution coefficients of $\mathrm{Co}$ and $\mathrm{Ni}$ decreased with oxygen partial pressure $\left(10^{-10}\right.$ to $10^{-6}$ atm $)$ from 1 to 0.005 and from 50 to 1 , respectively. The distribution coefficient of silver between copper and $\mathrm{Fe}-\mathrm{O}-\mathrm{CaO}$ slag decreased within the same $p_{\mathrm{O}_{2}}$ range from 3000 to 500 .

Yamaguchi $^{[18]}$ determined the distribution coefficients of $\mathrm{Ni}, \mathrm{Pt}$, and $\mathrm{Pd}$ between copper alloys and a $\mathrm{Fe}-\mathrm{O}-\mathrm{CaO}$ slag at $1300{ }^{\circ} \mathrm{C}$ in magnesia crucibles, in the oxygen partial pressure range from $10^{-9}$ to $10^{-5}$ atm. Slow quenching in argon flow with subsequent ICP analysis was employed for the equilibrated phases. The suggested values were $\mathrm{L}_{\mathrm{Ni}}^{\mathrm{Cu} / \mathrm{s}}=1$ to $20, \mathrm{~L}_{\mathrm{Pt}}^{\mathrm{Cu} / \mathrm{s}}$ and $\mathrm{L}_{\mathrm{Pd}}^{\mathrm{Cu} / \mathrm{s}}$ $\approx 1000$, with variable oxygen pressure slopes ( $\mathrm{Pd}$ was steeper).

Nishijima and Yamaguchi ${ }^{[19]}$ studied the distributions of PGMs between copper and magnesia-saturated $\mathrm{Al}_{2} \mathrm{O}_{3}-\mathrm{CaO}-\mathrm{SiO}_{2}-\mathrm{Cu}-\mathrm{O}$ slags at $1450{ }^{\circ} \mathrm{C}$ as a function of $p_{\mathrm{O}_{2}}\left(10^{-10}\right.$ to $\left.10^{-5} \mathrm{~atm}\right)$ and reported $\mathrm{L}_{\mathrm{Pt}}^{\mathrm{Cu} / \mathrm{s}}$ and $\mathrm{L}_{\mathrm{Pd}}^{\mathrm{Cu} / \mathrm{s}}$ decreasing from 2500 with increase of $p_{\mathrm{O}_{2}}$. Trend line for the platinum distribution coefficient had a steeper slope, and at the highest $p_{\mathrm{O}_{2}}$ the distribution coefficient was around 100, while for palladium it was around 300 . The distribution coefficients in lower oxygen partial pressures seemed to be independent of $p_{\mathrm{O}_{2}}$.

Kashima et al. ${ }^{[20]}$ studied distributions of various elements, including $\mathrm{Ag}, \mathrm{Ni}$, and $\mathrm{Co}$, in the silica-saturated copper-white metal-slag system at $1300{ }^{\circ} \mathrm{C}$, as a function of sulfur dioxide partial pressure $(0.007$ to 0.1 atm). The copper-slag distribution coefficients were approximately for $\mathrm{Ag}=70, \mathrm{Co}=0.1$ to 0.01 , and $\mathrm{Ni}$ $=10$ to 1 . $\mathrm{NiO}$ and $\mathrm{CoO}$ were suggested as the predominant species dissolving in the slag, while for $\mathrm{Ag}$ the effect of varying $p_{\mathrm{SO}_{2}}$ (and consequently $p_{\mathrm{O}_{2}}$ ) was not clear.

Copper-gold alloys were utilized in studies focused on determination of the activities of $\mathrm{CuO}_{0.5}$ in $\mathrm{Fe}-\mathrm{O}-\mathrm{SiO}_{2}$ slags, ${ }^{[21-23]}$ to vary the activity of copper in the system and to distinguish between the chemically dissolved and the mechanically entrained copper. Toguri and Santander $^{[23]}$ also studied the distribution of gold between copper and $\mathrm{Fe}-\mathrm{O}-\mathrm{SiO}_{2}$ slags as a function of temperature $\left(1250{ }^{\circ} \mathrm{C}\right.$ to $\left.1350{ }^{\circ} \mathrm{C}\right)$, oxygen partial pressure $\left(10^{-8}\right.$ to $\left.10^{-7} \mathrm{~atm}\right)$ and copper-gold alloy composition. Scattering values of gold solubility in the slag on the level of several hundreds of $\mathrm{ppm}$ were reported, with no correlation suggested.

Takeda and Roghani ${ }^{[24]}$ reported distributions of silver between copper metal and $\mathrm{Fe}-\mathrm{O}-\mathrm{CaO}-\mathrm{SiO}_{2}$ slags with various $\mathrm{CaO} / \mathrm{SiO}_{2}$ ratios at $1300{ }^{\circ} \mathrm{C}$. In the case of the Fe-O-SiO 2 slag, $\mathrm{L}_{\mathrm{Ag}}^{\mathrm{Cu}}$ decreased from 300 to 20 with increasing $p_{\mathrm{O}_{2}}$ from $10^{-8}$ to $10^{-4}$ atm. A significant effect of the slag basicity was observed, i.e., the 
distribution coefficient with $\mathrm{Fe}-\mathrm{O}-\mathrm{SiO}_{2}$ slag was about five times lower compared to the $\mathrm{Fe}-\mathrm{O}-\mathrm{CaO}$ slag. Hidayat et al. ${ }^{[2]}$ measured silver distributions between copper metal and an $\mathrm{Fe}-\mathrm{O}-\mathrm{SiO}_{2}$ slag at $1250{ }^{\circ} \mathrm{C}$ and in $10^{-9}$ to $10^{-7}$ atm $p_{\mathrm{O}_{2}}$. Measured distribution coefficients were reported to vary from about 800 to 150 , respectively.

Altman and Kellogg ${ }^{[22]}$ reported gold solubility in silica-saturated $\mathrm{Fe}-\mathrm{O}-\mathrm{SiO}_{2}$ slag to be around $80 \mathrm{ppmw}$ $\mathrm{Au}$ at temperatures from $1224{ }^{\circ} \mathrm{C}$ to $1286{ }^{\circ} \mathrm{C}$. Taylor and Jeffes ${ }^{[21]}$ measured a 40 to 80 ppmw Au solubility in iron silicate slags, at temperatures from $1300{ }^{\circ} \mathrm{C}$ to 1450 ${ }^{\circ} \mathrm{C}$, in oxygen partial pressures from $10^{-13}$ to $10^{-5} \mathrm{~atm}$ and with varying $\mathrm{Fe} / \mathrm{SiO}_{2}$ ratio, achieved by a substrate-free technique with a levitation cell. In addition, Swinbourne et al. ${ }^{[26]}$ reported that gold solubility in an $\mathrm{Fe}-\mathrm{O}-\mathrm{SiO}_{2}$ slag at $1300{ }^{\circ} \mathrm{C}$ increases from 100 to 400 ppmw with $p_{\mathrm{O}_{2}}$ from $10^{-9}$ to $10^{-7}$ atm. Their experiments involved equilibration of slag with pure molten gold in alumina crucibles. Baba and Yamaguchi ${ }^{[27]}$ reported platinum solubility in $\mathrm{Fe}-\mathrm{O}-\mathrm{SiO}_{2}$ slags at 1300 ${ }^{\circ} \mathrm{C}$ to be on the level of 3 to 7 ppmw, increasing with an increase in $p_{\mathrm{O}_{2}}\left(10^{-9}\right.$ to $\left.10^{-6} \mathrm{~atm}\right)$ and with increase of $\mathrm{Pt}$ fraction in the copper alloy (10 to $40 \mathrm{wt}$ pet $\mathrm{Pt}$ ). Around 10 wt pet $\mathrm{MgO}$ was reported dissolved in slag, due to $\mathrm{MgO}$ saturation. Several geological experimentalists propose much smaller solubilities for gold, palladium, and platinum in $\mathrm{Fe}-\mathrm{O}-\mathrm{SiO}_{2}$ slags and lowiron basalts. ${ }^{[28-30]}$

Shuva et al. ${ }^{[31]}$ studied the distribution of $\mathrm{Pd}$ between alloy and $\mathrm{Fe}-\mathrm{O}-\mathrm{CaO}-\mathrm{SiO}_{2}$ slags as a function of temperature $\left(1200{ }^{\circ} \mathrm{C}\right.$ to $1350{ }^{\circ} \mathrm{C}$, in $\mathrm{MgO}$ crucibles $), p_{\mathrm{O}_{2}}$ $\left(10^{-10}\right.$ to $\left.10^{-7} \mathrm{~atm}\right)$ and slag composition, by varying $\mathrm{CaO}$ concentration from 5 to 20 wt pct. $\mathrm{L}_{\mathrm{Pd}}^{\mathrm{Cu} / \mathrm{s}}$ was reported to be on the level of 100 to 1000 , decreasing with an increase in $p_{\mathrm{O}_{2}}$ and increasing with increasing temperature.

In our laboratory, using the same experimental technique as this study, the distributions of $\mathrm{Ag}$ and $\mathrm{Au}$ between metallic copper and alumina-saturated $\mathrm{Fe}-\mathrm{O}$ $\mathrm{SiO}_{2}$ slag have been measured at $1300{ }^{\circ} \mathrm{C}$ as a function of $p_{\mathrm{O}_{2}}$. The distribution coefficient of silver decreased from 1000 to 30 with increase in $p_{\mathrm{O}_{2}}$ from $10^{-10}$ to $10^{-5}$ atm, and the distribution coefficient of gold at $p_{\mathrm{O}_{2}}=$ $10^{-5}$ atm was determined as $\mathrm{L}_{\mathrm{Au}}^{\mathrm{Cu}}=10^{5}$, and it was greater than or equal to $10^{6}$ at lower $p_{\mathrm{O}_{2}}$. ${ }^{[32]}$

\section{EXPERIMENTAL}

The experimental technique employed in this study combined a high-temperature isothermal equilibration of metallic copper with silica-saturated iron silicate slag, at ambient pressure and under fixed oxygen partial pressure, followed by a rapid quenching and direct analyses of the retained equilibrium assembly and phase compositions at room temperature.

The Gibbs phase rule is a helpful tool for describing the system in a concise way and analyzing a complex heterogeneous equilibrium with reactive components. ${ }^{[33]}$ The present base system is comprised of five components
$\left(\mathrm{Cu}, \mathrm{Fe}, \mathrm{O}, \mathrm{CO}_{2}\right.$ and $\left.\mathrm{SiO}_{2}\right)$ with four coexisting phases (solid silica, molten slag, molten copper, and gas). Therefore, two degrees of freedom remain to fully fix the isobaric system and establish equilibrium, which are temperature and oxygen partial pressure. Beyond that, every trace element added to the system increased the number of degrees of freedom by one and their distribution coefficients are measured in this study.

\section{A. Synthesis of Master Alloy}

The trace elements $\mathrm{Ni}, \mathrm{Co}, \mathrm{Ag}, \mathrm{Au}, \mathrm{Pt}$, and $\mathrm{Pd}$ were introduced into the system as pure metals. A master alloy containing $94 \mathrm{wt}$ pct copper and $1 \mathrm{wt}$ pct of each trace element (Ag, $\mathrm{Au}, \mathrm{Co}, \mathrm{Ni}, \mathrm{Pd}$, and $\mathrm{Pt}$ ) was prepared prior to the distribution experiments. Copper shots and pelletized trace element powders (Table I) were placed into a fused silica ampoule. The ampoule was flushed with 99.999 vol pet pure argon (AGA-Linde, Finland) and evacuated to $2 \times 10^{-2}$ mbar, prior to sealing it with an $\mathrm{O}_{2}-\mathrm{H}_{2}$ torch. The alloy was synthesized in a vertical resistance tube furnace at $1200{ }^{\circ} \mathrm{C}$ for 180 hours. The equilibrated master alloy was water-quenched. ${ }^{[32]}$

\section{B. The Setup and Procedure}

The distribution experiments were conducted in a vertical resistance furnace equipped with an alumina work tube Degussit AL23 (Friatec, Germany), impermeable to gas (Figure 1). The oxygen partial pressure was fixed by mixtures of either $\mathrm{CO}-\mathrm{CO}_{2}$ or $\mathrm{CO}_{2}-\mathrm{N}_{2}$ (Table II). The chemically pure gases were supplied by AGA-Linde (Finland), CO 99.97 vol pct, $\mathrm{CO}_{2} 99.9993$ vol pet, and $\mathrm{N}_{2} 99.999$ vol pet. DFC26 mass-flow controllers (Aalborg, USA) were employed to regulate the gas flow rates, and the gases were mixed in a column filled with ceramic pebbles at room temperature. The

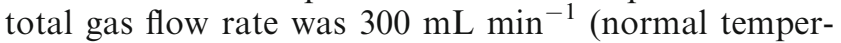
ature and pressure) in all experiments. The experimental temperature was measured with a calibrated S-type, $\mathrm{Pt} /$ Pt-10 pctRh thermocouple (Johnson-Matthey Noble Metals, UK) next to the sample during the entire equilibration (accuracy of $\pm 2^{\circ} \mathrm{C}$ ). The thermocouple was connected to a multimeter (Keithley 2010 DMM). A Pt100 resistance thermometer (tolerance class B 1/10; SKS-Group, Finland) connected to a multimeter (Keithley 2000 DMM) measured the cold junction temperature.

The molten copper and molten slag were equilibrated in small bowl-shaped fused silica crucibles $(10 \mathrm{~mm}$ outer diameter, 6 mm height, 99.98 wt pct pure; OM Lasilaite, Finland) suspended in the hot isothermal zone of the furnace (Figure 1). Pieces of the master alloy and a mixture of oxides were used as starting materials for the distribution experiments. The oxide mixture was comprised of $30 \mathrm{wt}$ pct $\mathrm{SiO}_{2}$ (pulverized in agate mortar) and 70 wt pet $\mathrm{Fe}_{2} \mathrm{O}_{3}$ (Table I). About 60 to $80 \mathrm{mg}$ of the master alloy and an equal amount of the oxide mixture were placed in a fused silica crucible. A platinum wire (99.99 wt pet pure; Johnson Matthey Noble Metals, UK), $0.5 \mathrm{~mm}$ in diameter and a basket made of it were used for the crucible suspension. The location of the 
Table I. The Materials Utilized for Copper Alloy and the Iron Silicate Slag

\begin{tabular}{lcll}
\hline Chemical & Purity (Wt Pct) & Form & Supplier \\
\hline $\mathrm{Cu}$ & 99.999 & shot & Alfa Aesar, Germany \\
$\mathrm{Ni}$ & 99.996 & powder & Alfa Aesar, Germany \\
$\mathrm{Co}$ & 99.99 & sponge & Koch-Light Laboratories Ltd, UK \\
$\mathrm{Ag}$ & 99.99 & powder & Alfa Aesar, Germany \\
$\mathrm{Au}$ & 99.96 & powder & Alfa Aesar, Germany \\
$\mathrm{Pt}$ & 99.98 & powder & Alfa Aesar, Germany \\
$\mathrm{Pd}$ & 99.9 & powder & Alfa Aesar, Germany \\
$\mathrm{Fe}$ & 99.99 & pieces & Alfa Aesar, Germany \\
$\mathrm{SiO}_{2}$ & 99.99 & granulate & Umicore, Germany \\
$\mathrm{Fe}_{2} \mathrm{O}_{3}$ & 99.99 & powder & Alfa Aesar, Germany \\
\hline
\end{tabular}
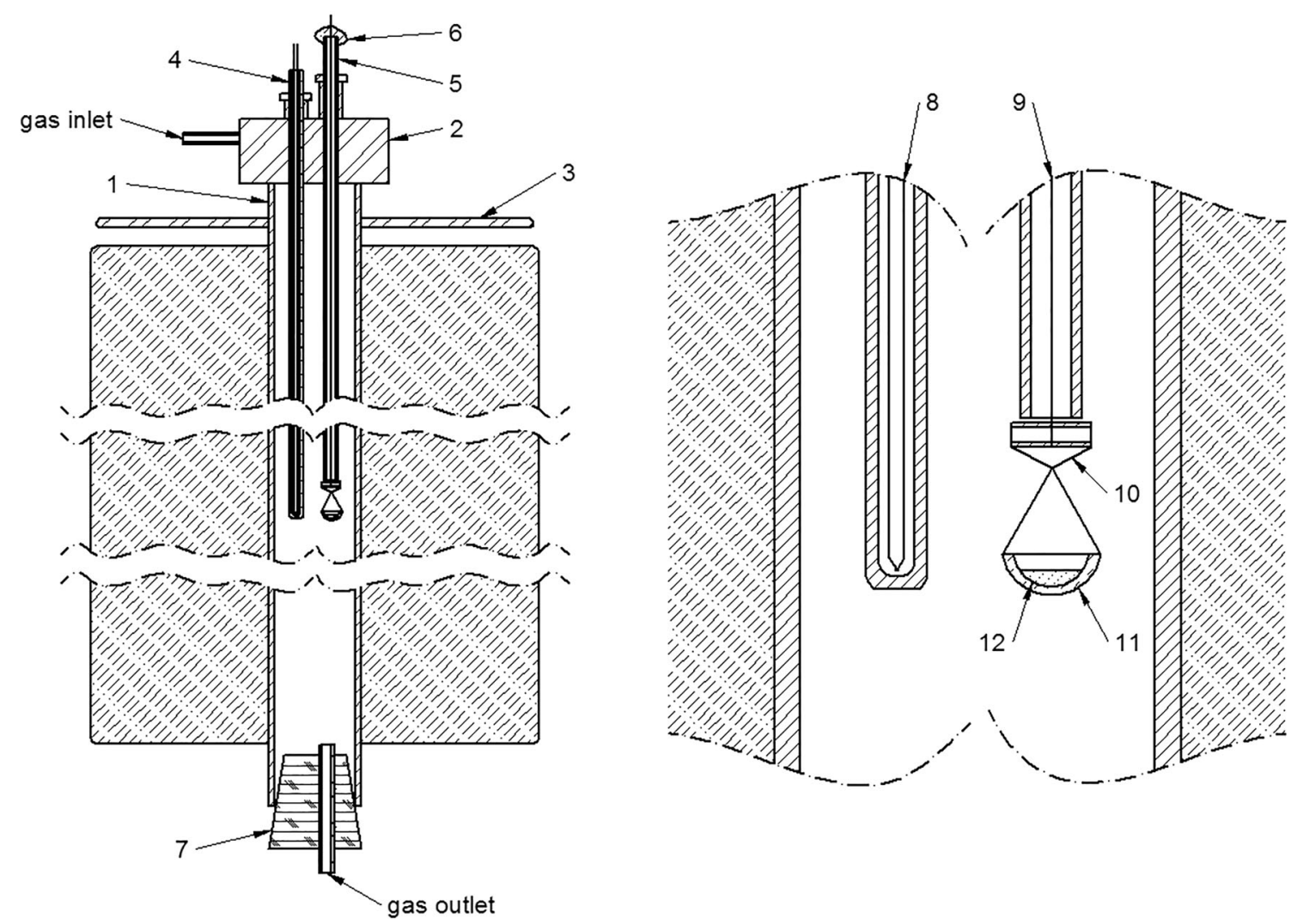

Fig. 1-Schematics of the experimental furnace (left) and the sample arrangement (right): 1 alumina work tube, 2 water-cooled furnace head, 3 water-cooled shield, 4 thermocouple alumina sheath, 5 alumina guiding tube, 6 adhesive tack sealing, 7 rubber cork, 8 thermocouple, 9 Pt suspension wire, $10 \mathrm{Pt}$ basket with alumina tube, 11 fused silica crucible, 12 sample.

furnace hot zone was determined beforehand by measuring the temperature profile of the furnace along the working tube.

The equilibrated samples were rapidly quenched to a chilled $\mathrm{NaCl}$-water solution $\left(t=-8{ }^{\circ} \mathrm{C} \pm 2{ }^{\circ} \mathrm{C}\right)$. The small sample weight facilitated high cooling rate and aided in retaining the high-temperature equilibrium compositions and structures of the phases.

\section{Sample Preparation for Elemental Analysis}

The quenched samples were rinsed with fresh water, dried at room temperature, and subsequently mounted in EpoFix epoxy resin (Struers, Denmark). Cross sections were prepared employing routine metallographic methods of wet grinding and polishing. A Leica EM SCD050 sputtering device (Leica Mikrosysteme, Austria) was employed to carbon-coat the polished 
sections for examination of the microstructures and elemental analysis of the equilibrium phases. Preliminary examination of the samples was conducted using a LEO 1450 (Carl Zeiss Microscopy, Germany) scanning electron microscope (SEM) coupled to an Oxford Instruments X-Max $50 \mathrm{~mm}^{2}$ energy dispersive spectrometer (EDS) (Oxford Instruments, UK). Further analyses with a particular emphasis on trace element concentrations were conducted using electron probe X-ray microanalysis (EPMA) and laser ablation-inductively coupled plasmamass spectrometry (LA-ICP-MS) techniques, as described in detail in Sections II-D and II-E.

\section{Electron Probe Microanalysis}

Elemental compositions of the copper alloy and slag were determined with a Cameca SX100 EPMA (Cameca SAS, France) equipped with five wavelength dispersive spectrometers (WDS). The number of measurements in each phase was eight. The beam diameter was $100 \mu \mathrm{m}$ for the metal phase and $50 \mu \mathrm{m}$ for the slag phase. Table III shows the standards and the respective X-ray lines utilized. The accelerating voltage and the beam current employed were $20 \mathrm{kV}$ and $80 \mathrm{nA}$, respectively. Totals of the EPMA analyses ranged from 98 to 100 pct.

\section{E. Laser Ablation-Inductively Coupled Plasma-Mass Spectrometry}

In laser ablation, the introduction of the sample into a plasma is employed. Material is removed from a solid surface of the specimen (Figure 2) by laser irradiation, forming a plume of ablated material in helium gas. Sample plus He carrier gas is then mixed with argon make-up gas before entering the argon plasma, where it is ionized for subsequent quantitative isotopic analysis of the elements. ${ }^{[34,35]}$

A Photon Machines Analyte Excite Laser Ablation System with $193 \mathrm{~nm}$ wavelength ArF excimer laser (Teledyne CETAC Technologies) coupled to a $\mathrm{Nu}$ AttoM single collector sector field ICP-MS (Nu Instruments, UK) was employed for in situ elemental analysis of the slag phase. Material was ablated from selected spots (see Figure 2) of the glassy slag located with the aid of an on-board high definition (down to $2 \mu \mathrm{m}$ ) zoom optical microscope system. The spot diameter and the laser fluence were $85 \mu \mathrm{m}$ and $1.92 \mathrm{~J} \mathrm{~cm}^{-1}$, respectively. The laser was operated at $10 \mathrm{~Hz}$ frequency starting with 5 pulses of pre-ablation for removal of the carbon coating from the surface and other contamination, followed by a 20 -second pause for system clean-out, a 20 -second on-peak baseline measurement followed by 400 analysis pulses. The mass spectrometer was operated in FastScan mode with low resolution $(\Delta M / M=300)$ to maximize sensitivity.

NIST 612 SRM $^{[36]}$ and Si (by EPMA data) were employed as external and internal standards, respectively. USGS BHVO-2G and BCR-2G basaltic glasses, as well as NIST 610 SRM were analyzed as unknowns for monitoring the hardware conditions and analysis quality. Glitter software package ${ }^{[37]}$ did the raw data processing, i.e., baseline reduction and quantifications.

Concentrations of the following isotopes were measured in the LA-ICP-MS analysis: ${ }^{59} \mathrm{Co},{ }^{60} \mathrm{Ni},{ }^{62} \mathrm{Ni}$, ${ }^{104} \mathrm{Pd},{ }^{106} \mathrm{Pd},{ }^{108} \mathrm{Pd},{ }^{107} \mathrm{Ag},{ }^{109} \mathrm{Ag},{ }^{194} \mathrm{Pt},{ }^{195} \mathrm{Pt},{ }^{196} \mathrm{Pt}$, and ${ }^{197} \mathrm{Au}$. The isotopes were selected with regards to possible interferences and natural abundances. The measured values of the concentrations were averaged in the cases when the concentration of an element was obtained using several isotopes. In this study, palladium was the most problematic element from analytical viewpoint. Its most commonly used isotope for quantification in the ICP-MS technique is ${ }^{105} \mathrm{Pd}$. However, significant mass interference exists with copper argide $\left({ }^{40} \mathrm{Ar}^{65} \mathrm{Cu}^{+}\right)$formed in argon plasma of the ICP when copper containing samples are analyzed. ${ }^{[38]}$ Therefore, three other $\mathrm{Pd}$ isotopes were used. All of them have interferences with other elements in the NIST 612 SRM standard, i.e., ${ }^{104} \mathrm{Pd}$ with ${ }^{104} \mathrm{Ru},{ }^{106} \mathrm{Pd}$ with ${ }^{106} \mathrm{Cd}$, and ${ }^{108} \mathrm{Pd}$ with ${ }^{108} \mathrm{Cd}$. The first one is negligible, because ruthenium concentration in the standard is several orders of magnitude lower than that of palladium. The cadmium-related interference was removed mathematically from the raw data of ${ }^{106} \mathrm{Pd}$ and ${ }^{108} \mathrm{Pd}$ concentrations by incorporating an appropriate correction factor. $^{[39]}$

Table II. Temperatures and Gas Mixtures Utilized in the Experiments

\begin{tabular}{|c|c|c|c|c|}
\hline$\left({ }^{\circ} \mathrm{C}\right)$ & CO Flow $\left(\mathrm{mL} \min ^{-1}\right)$ & $\mathrm{CO}_{2}$ Flow $\left(\mathrm{mL} \min ^{-1}\right)$ & $\mathrm{N}_{2}$ Flow $\left(\mathrm{mL} \min ^{-1}\right)$ & Target $p_{\mathrm{O}_{2}}(\mathrm{~atm})$ \\
\hline \multirow[t]{2}{*}{1250} & 19.8 & 280.2 & - & $10^{-8.0}$ \\
\hline & 6.6 & 293.4 & - & $10^{-7.0}$ \\
\hline \multirow[t]{5}{*}{1300} & 37.7 & 262.3 & - & $10^{-8.0}$ \\
\hline & 13.0 & 287.0 & - & $10^{-7.0}$ \\
\hline & 4.3 & 295.7 & - & $10^{-6.0}$ \\
\hline & 1.4 & 298.6 & - & $10^{-5.0}$ \\
\hline & - & 80.5 & 219.5 & $10^{-4.0}$ \\
\hline \multirow[t]{5}{*}{1350} & 65.6 & 234.4 & - & $10^{-8.0}$ \\
\hline & 24.4 & 275.6 & - & $10^{-7.0}$ \\
\hline & 8.2 & 291.8 & - & $10^{-6.0}$ \\
\hline & 2.6 & 297.4 & - & $10^{-5.0}$ \\
\hline & - & 51.7 & 248.3 & $10^{-4.0}$ \\
\hline
\end{tabular}




\section{F. Equilibration Time and Repeatability}

In a preliminary time series of experiments, sufficient equilibration time was determined to be 12 hours. Therefore, all experiments in the main series were conducted with this equilibration time. From the main series of experiments, it was observed that at $p_{\mathrm{O}_{2}}=10^{-4}$ atm, the copper fraction in the copper alloy was significantly lower than at the lower oxygen partial pressures. Thus, these experiments were repeated with an addition of $\mathrm{Cu}_{2} \mathrm{O}$ to the starting mixture. $\mathrm{Cu}_{2} \mathrm{O}$ was produced from pure $99.99+$ wt pct copper cathode by prolonged oxidation in air at $1026{ }^{\circ} \mathrm{C}$, as described previously. ${ }^{[40]}$

One experiment was conducted at $p_{\mathrm{O}_{2}}=10^{-8} \mathrm{~atm}$ and at $1350{ }^{\circ} \mathrm{C}$ with different starting materials to assure the equilibrium was attained. Specifically, pulverized metallic iron (Table I) was used instead of $\mathrm{Fe}_{2} \mathrm{O}_{3}$, besides the used master alloy and $\mathrm{SiO}_{2}$. This sample was equilibrated for 48 hours, because oxidation of iron

Table III. The Standards Employed in the EPMA Analyses

\begin{tabular}{llc}
\hline Element & \multicolumn{1}{c}{ Standard } & X-ray Line \\
\hline Oxygen & hematite $\left(\mathrm{Fe}_{2} \mathrm{O}_{3}\right)$ & $\mathrm{O} \mathrm{K}{ }_{\alpha}$ \\
Silicon & quartz $\left(\mathrm{SiO}_{2}\right)$ & $\mathrm{Si} \mathrm{K} \alpha$ \\
Iron & hematite $\left(\mathrm{Fe}_{2} \mathrm{O}_{3}\right)$ & $\mathrm{Fe} \mathrm{K}$ \\
Cobalt & cobaltite $(\mathrm{CoAsS})$ & $\mathrm{Co} \mathrm{K}$ \\
Nickel & pentlandite $\left((\mathrm{Fe}, \mathrm{Ni})_{9} \mathrm{~S}_{8}\right)$ & $\mathrm{Ni} \mathrm{K}_{\alpha}$ \\
Copper & pure metallic copper & $\mathrm{Cu} \mathrm{K}$ \\
Palladium & pure metallic palladium & $\mathrm{Pd} \mathrm{L}_{\alpha}$ \\
Platinum & pure metallic platinum & $\mathrm{Pt} \mathrm{L}_{\alpha}$ \\
Gold & pure metallic gold & $\mathrm{Au} \mathrm{L} \alpha_{\alpha}$ \\
Silver & pure metallic silver & $\mathrm{Ag} \mathrm{L}$ \\
\hline
\end{tabular}

was expected to be slower than reduction of hematite, utilized in the main series of experiments. In addition, selected duplicate experiments were conducted in the same way as in the main series as a test level of the repeatability. The results acquired in all the experiments conducted were summarized and are discussed below (see also data in Supplementary Material, refer to Electronic Supplementary Material).

\section{RESULTS AND DISCUSSION}

The distribution coefficients of base metals $\mathrm{Cu}, \mathrm{Fe}$, $\mathrm{Ni}$, and $\mathrm{Co}$, and noble metals $\mathrm{Ag}, \mathrm{Au}, \mathrm{Pt}$, and $\mathrm{Pd}$ were determined in experimental runs conducted at three temperatures, $1250{ }^{\circ} \mathrm{C}, 1300^{\circ} \mathrm{C}, 1350^{\circ} \mathrm{C}$ and five oxygen partial pressures, $10^{-8}, 10^{-7}, 10^{-6}, 10^{-5}$, and $10^{-4} \mathrm{~atm}$, as shown in Table II. Previous observations ${ }^{[17,41]}$ regarding magnetite separation from $\mathrm{Fe}-\mathrm{O}-\mathrm{SiO}_{2}$ slag at $1250{ }^{\circ} \mathrm{C}$ occurring at $p_{\mathrm{O}_{2}}$ above $10^{-7}$ atm were confirmed experimentally and by thermodynamic calculations using MTDATA software and MTOX v. 8.1 database. ${ }^{[42]}$ Figure 3 shows that at $1250{ }^{\circ} \mathrm{C}$, the molten oxide (slag) in the $\mathrm{Cu}-\mathrm{Fe}-\mathrm{O}-\mathrm{SiO}_{2}$ system is stable at oxygen partial pressures below $10^{-6}$ atm. Therefore at $1250^{\circ} \mathrm{C}$, the distribution coefficient measurements were limited to the $p_{\mathrm{O}_{2}}$ range from $10^{-8}$ to $10^{-7} \mathrm{~atm}$.

\section{A. Microstructures of the Samples in Equilibrium}

Figure 4 shows micrographs of equilibrated samples post quenching [(a) $\theta=1300{ }^{\circ} \mathrm{C}, p_{\mathrm{O}_{2}}=10^{-7} \mathrm{~atm}$ and (b) $\left.\theta=1300{ }^{\circ} \mathrm{C}, p_{\mathrm{O}_{2}}=10^{-4} \mathrm{~atm}\right]$, demonstrating the general microstructures and equilibrium phases. The

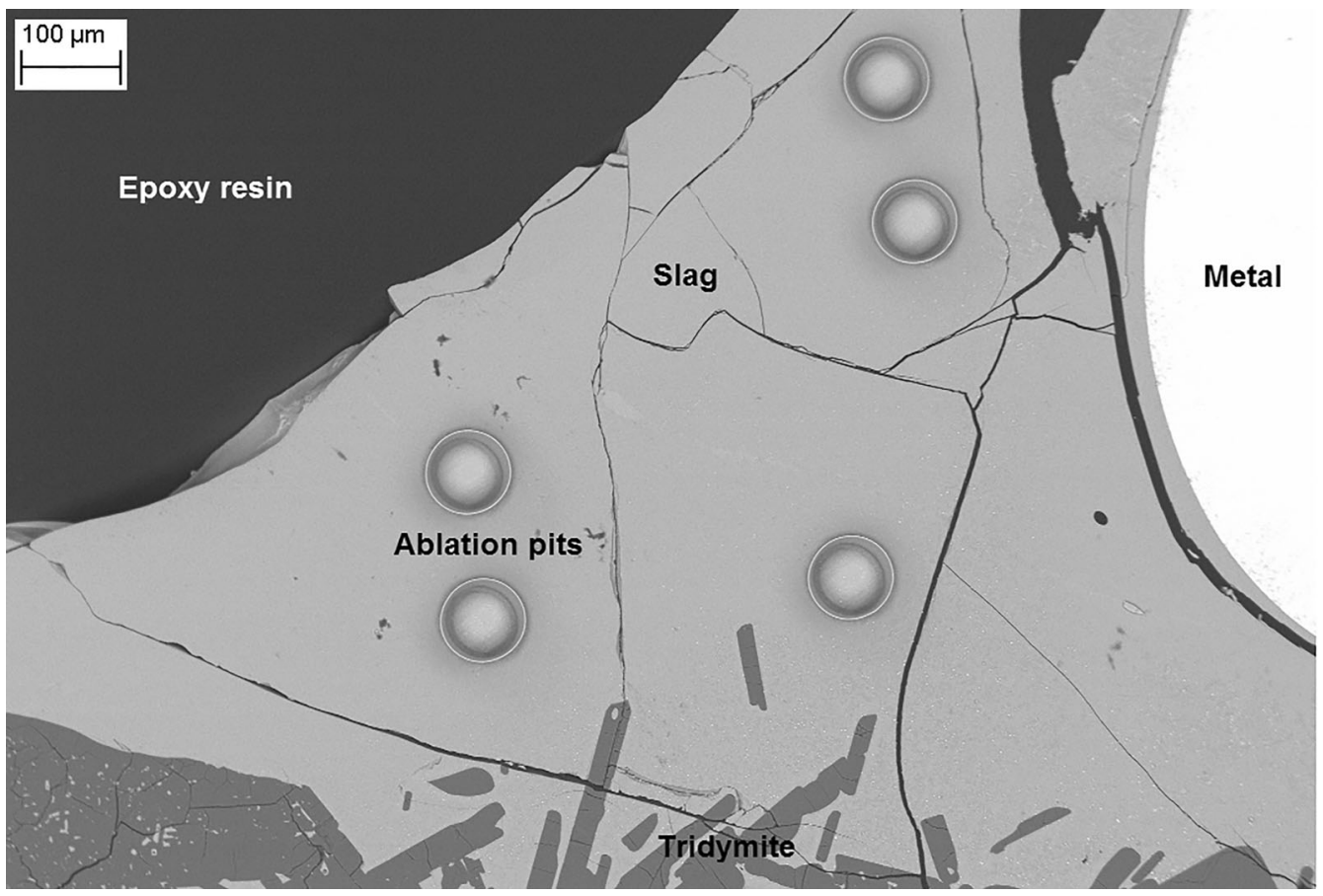

Fig. 2-Ablation pits formed in the glassy slag phase during LA-ICP-MS analysis; a SEM backscattered electron image. 


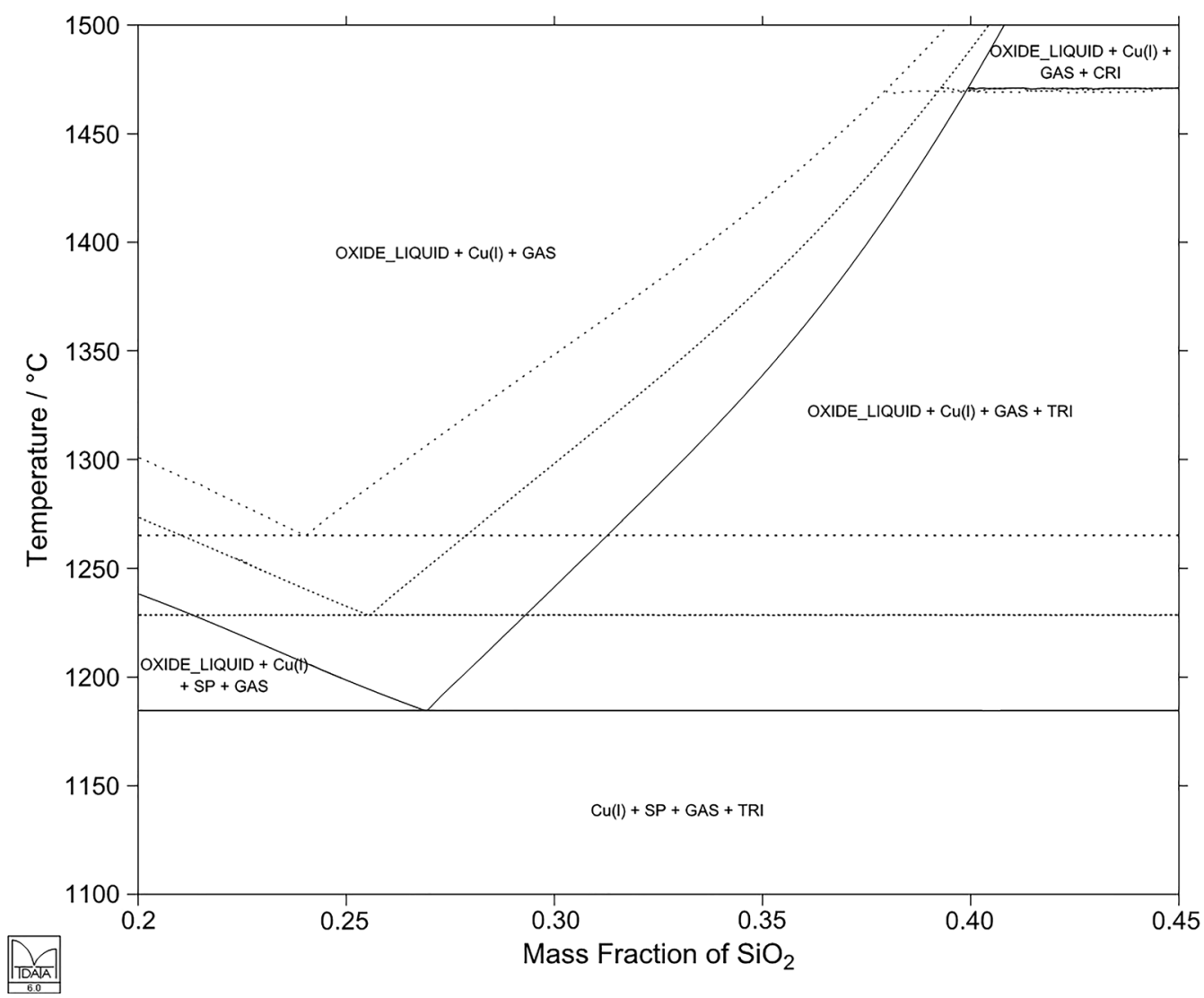

Fig. 3- Calculated isopleths of the $\mathrm{Cu}-\mathrm{Fe}-\mathrm{O}-\mathrm{SiO}_{2}$ system at $p_{\mathrm{O}_{2}}=10^{-6}$ to $10^{-8}$ atm (solid line $10^{-6}$; dashed line $10^{-7}$; dotted line $10^{-8}$ atm;

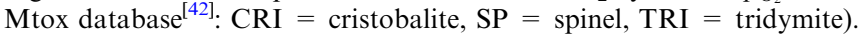

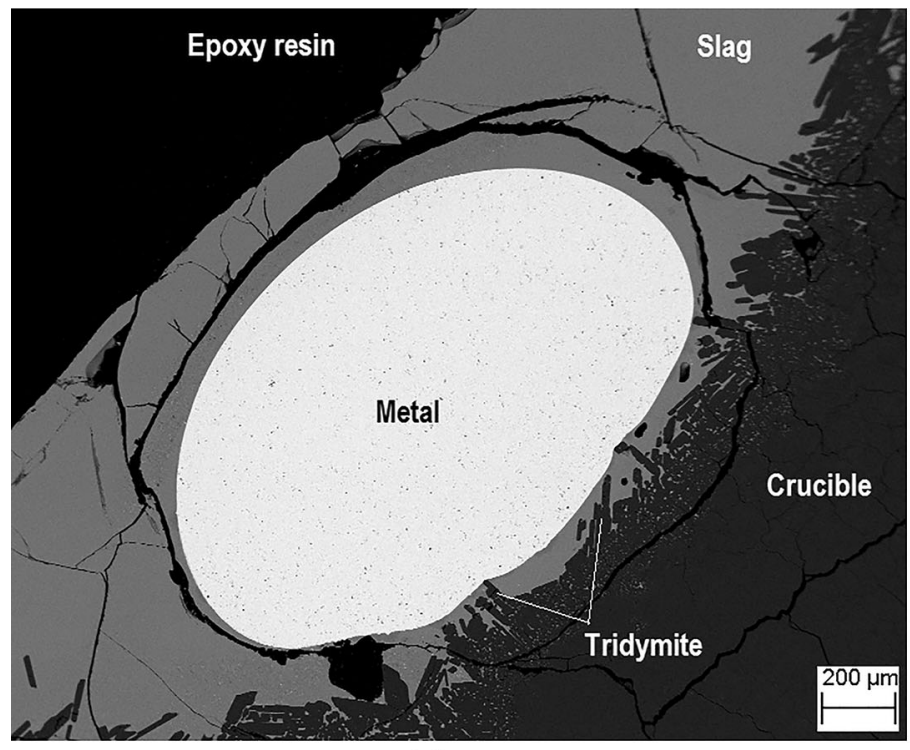

(a)

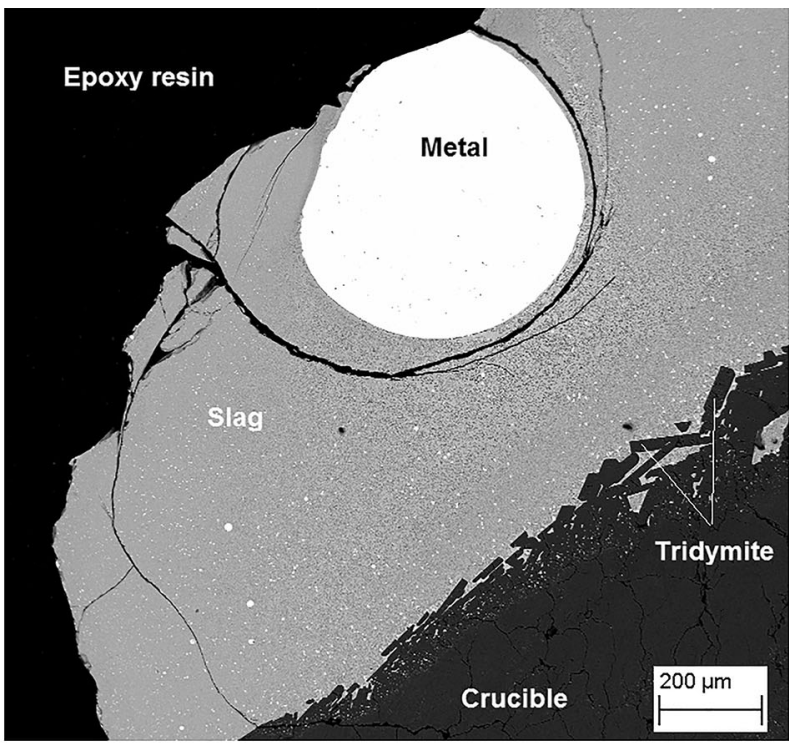

(b)

Fig. 4-A typical sample morphology: (a) $\theta=1300{ }^{\circ} \mathrm{C}, p_{\mathrm{O}_{2}}=10^{-7} \mathrm{~atm} ;(b) \theta=1300{ }^{\circ} \mathrm{C}, p_{\mathrm{O}_{2}}=10^{-4}$ atm (SEM backscattered electron images).

samples are comprised of the metal alloy, the slag phase, elongated crystals of tridymite (solid, secondary silica) and the crucible (fused vitreous silica). In general, this microstructure was uniform for all samples. However, the samples equilibrated at higher oxygen partial pressures have much higher concentrations of copper 
dissolved in the slag. It has been previously reported ${ }^{[43]}$ and observed also in the present study that, liquid oxides and silicates with high copper concentrations have a poor quenching ability and a tendency to form copper-rich precipitates. More specifically, the molten slag in the samples equilibrated at $10^{-8}$ to $10^{-7}$ atm oxygen partial pressure formed a nearly homogeneous glassy structure post quenching (Figure 4(a)), while those equilibrated at $10^{-6}$ to $10^{-4} \mathrm{~atm}$ formed copper rich precipitates in the slag (Figure 4(b)). To minimize analytical errors, the well quenched (glassy or microcrystalline) slag areas were selected, and a relatively large spot size was employed.

\section{B. Slag Composition}

Iron-to-silica ratio (wt pet $\left.\mathrm{Fe}_{\text {tot }}\right) /\left(\right.$ wt pet $\left.\mathrm{SiO}_{2}\right)$ is a characteristic of slags that is commonly used as a control variable in the industry. Under the present experimental conditions, the silica-saturated $\mathrm{Fe}-\mathrm{O}-\mathrm{SiO}_{2}$ slag had a $\mathrm{Fe} / \mathrm{SiO}_{2}$ ratio ranging from 0.70 to 1.45 (Figure 5). In general, the ratio slightly increases with $p_{\mathrm{O}_{2}}{ }^{[25]}$ up to $10^{-6} \mathrm{~atm}$ and decreases with temperature. However, at $p_{\mathrm{O}_{2}}$ around $10^{-6}$ to $10^{-5}$ atm, the copper concentration in the slag became so high $(10$ wt pet $\mathrm{Cu}$ and higher) that it contributed significantly to the total slag composition, mainly decreasing the iron content and consequently decreasing the $\mathrm{Fe} / \mathrm{SiO}_{2}$ ratio (especially at $\left.p_{\mathrm{O}_{2}}=10^{-4} \mathrm{~atm}\right)$. In addition, at $p_{\mathrm{O}_{2}}=10^{-4}$ atm an effect of copper concentration in the metallic phase on the slag composition was evident (Figure 5), i.e., increasing concentration of copper in the slag reduced the $\mathrm{Fe} / \mathrm{SiO}_{2}$ ratio. The chemically dissolved copper concentration in slag varied from 2 to $45 \mathrm{wt}$ pct $\mathrm{Cu}$, increasing with increasing $p_{\mathrm{O}_{2}}$ and decreasing slightly with an increase in temperature, as shown Figure 6.

The former correlation is evident, because copper dissolves in the slag in the form of $\mathrm{CuO}_{0.5},{ }^{[41]}$ while regarding the latter, interesting trends were reported in the literature, the solubility of copper in acidic slags reduces with increase in temperature, ${ }^{[23]}$ and in basic slags the trend is the opposite. ${ }^{[44]}$ It is worth noticing that this refers to the true chemical solubility, which can be a secondary reason for industrial copper losses in slag, while mechanically entrained copper may be the primary source. ${ }^{[45]}$

\section{Validation of the Analytic Techniques Applied}

The metallic alloy was well characterized with EPMA, including its solute element concentrations. The slag was also characterized with EPMA, but its equilibrium concentrations of PMs and PGMs fall well below the EPMA detection limits. Therefore, in order to measure their concentrations accurately, the slag was additionally characterized with the LA-ICP-MS technique. The typical detection limits of EPMA for elements analyzed in the present study ranged from one hundred to several hundreds of ppmw (Table IV), while LA-ICP-MS is a technique mainly focused on analysis of ppm and sub-ppm levels of trace element concentrations.

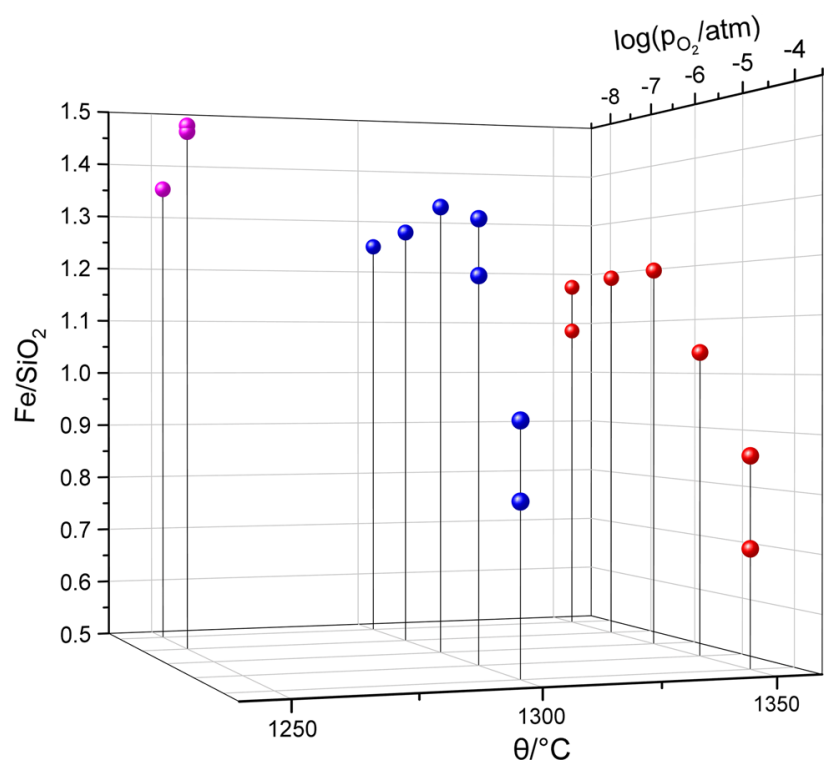

Fig. $5-\mathrm{Fe} / \mathrm{SiO}_{2}$ ratio $(\mathrm{w} / \mathrm{w})$ as a function of temperature and oxygen partial pressure.

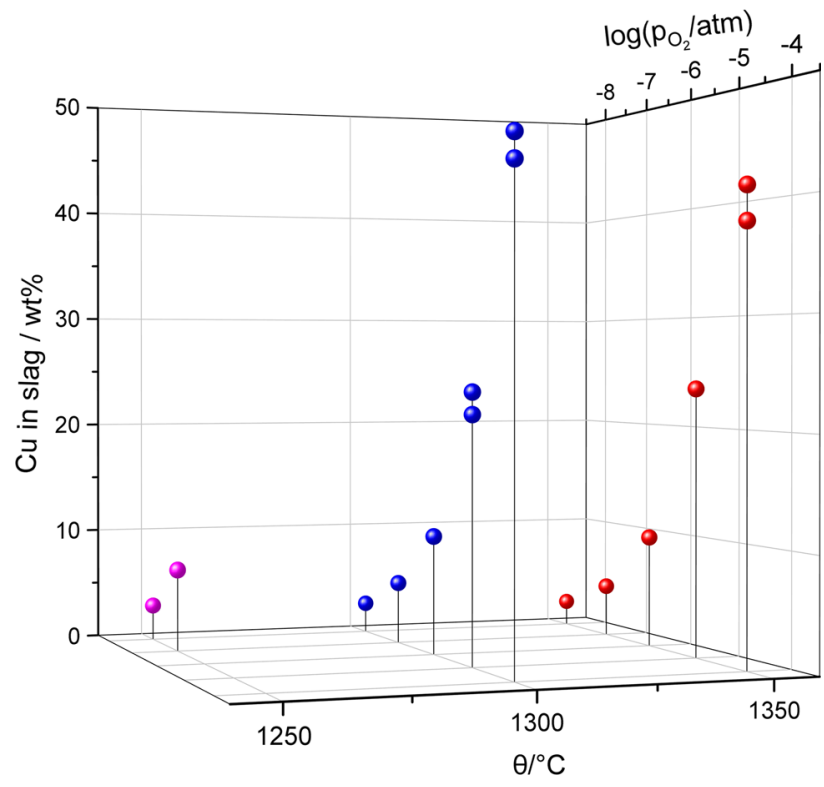

Fig. 6 - Concentration of copper dissolved in slag as a function of temperature and oxygen partial pressure.

LA-ICP-MS detection limits depend on the sensitivity, background noise, and signal measurement time. The background noise is a function of the instrument baseline at the mass measured, while the sensitivity depends on multiple variables, most importantly on the mass of the material ablated, ${ }^{[34]}$ as well as on the matrix of the phase analyzed, and the element of interest, its concentration, ionization potential, and the abundance of the isotope measured. Hence, in the slag-phase characterization, the detection limits varied slightly from sample to sample, and to a small extent among 
Table IV. The Detection Limits of EPMA for the Elements Analyzed

\begin{tabular}{|c|c|c|c|c|c|c|c|c|c|c|}
\hline \multirow[b]{2}{*}{ Phase } & \multicolumn{10}{|c|}{ Detection Limit (ppmw) } \\
\hline & $\mathrm{O}$ & $\mathrm{Si}$ & $\mathrm{Fe}$ & Co & $\mathrm{Ni}$ & $\mathrm{Cu}$ & $\mathrm{Pd}$ & $\mathrm{Pt}$ & $\mathrm{Au}$ & $\mathrm{Ag}$ \\
\hline Metal & 1000 & 200 & 160 & 70 & 90 & 310 & 150 & 450 & 600 & 160 \\
\hline Slag & 1100 & 160 & 170 & 80 & 80 & 260 & 120 & 380 & 510 & 140 \\
\hline
\end{tabular}

Table V. The Detection Limits of LA-ICP-MS for the Isotopes Used in the Analyses

\begin{tabular}{lcccccccccccc}
\hline \multicolumn{10}{c}{ Detection Limit (ppbw) } \\
\hline${ }^{59} \mathrm{Co}$ & ${ }^{60} \mathrm{Ni}$ & ${ }^{62} \mathrm{Ni}$ & ${ }^{104} \mathrm{Pd}$ & ${ }^{106} \mathrm{Pd}$ & ${ }^{108} \mathrm{Pd}$ & ${ }^{107} \mathrm{Ag}$ & ${ }^{109} \mathrm{Ag}$ & ${ }^{194} \mathrm{Pt}$ & ${ }^{195} \mathrm{Pt}$ & ${ }^{196} \mathrm{Pt}$ & ${ }^{197} \mathrm{Au}$ \\
\hline 4 to 6 & 40 to 70 & 220 to 300 & 10 to 17 & 3 to 11 & 3 to 8 & 2 to 5 & 2 to 3 & 1 & 1 & 1 \\
\hline
\end{tabular}

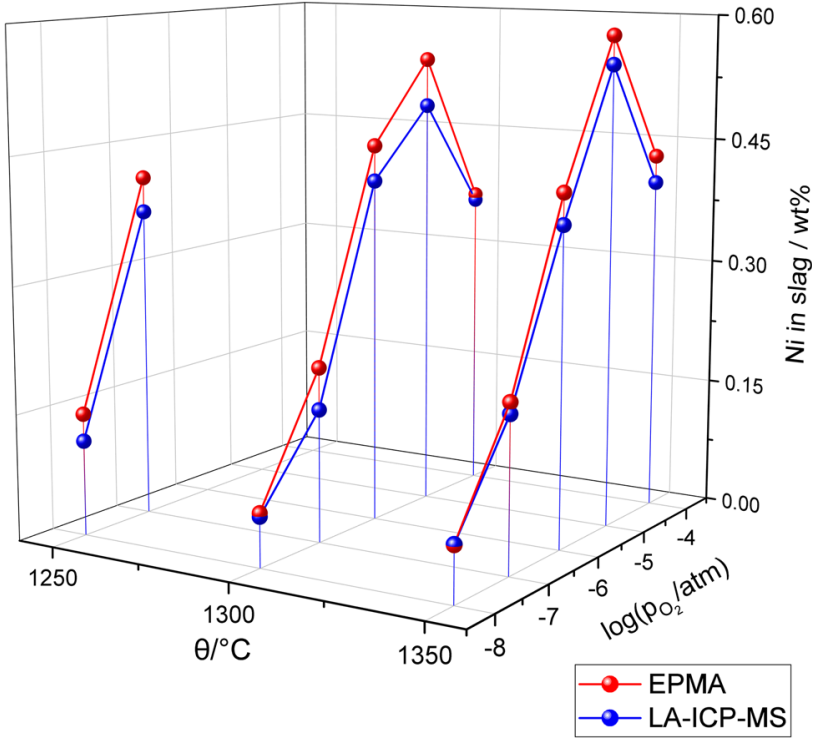

Fig. 7-Equilibrium concentrations of $\mathrm{Ni}$ in the slag as a function of temperature and oxygen partial pressure measured using different analytic techniques.

the measurement points for a single sample. The LA-ICP-MS detection limit values for each element are summarized in Table V. Particularly, they range from one to ten ppbw for Co, PMs, and PGMs, whereas for $\mathrm{Ni}$, they are about one or two orders of magnitude higher (see Table V).

In several samples, the concentrations of $\mathrm{Ni}$ and $\mathrm{Co}$ dissolved in the slag fell in the range, where both analytic techniques were applicable. Therefore, the values measured with both techniques could be compared for validation purposes. In most cases, the Ni and Co concentrations measured with LA-ICP-MS technique were systematically lower (by 10 to 20 pct) than those measured with EPMA (Figures 7 and 8, respectively). However, at the lower side of concentrations the values matched well, providing the credibility to the data

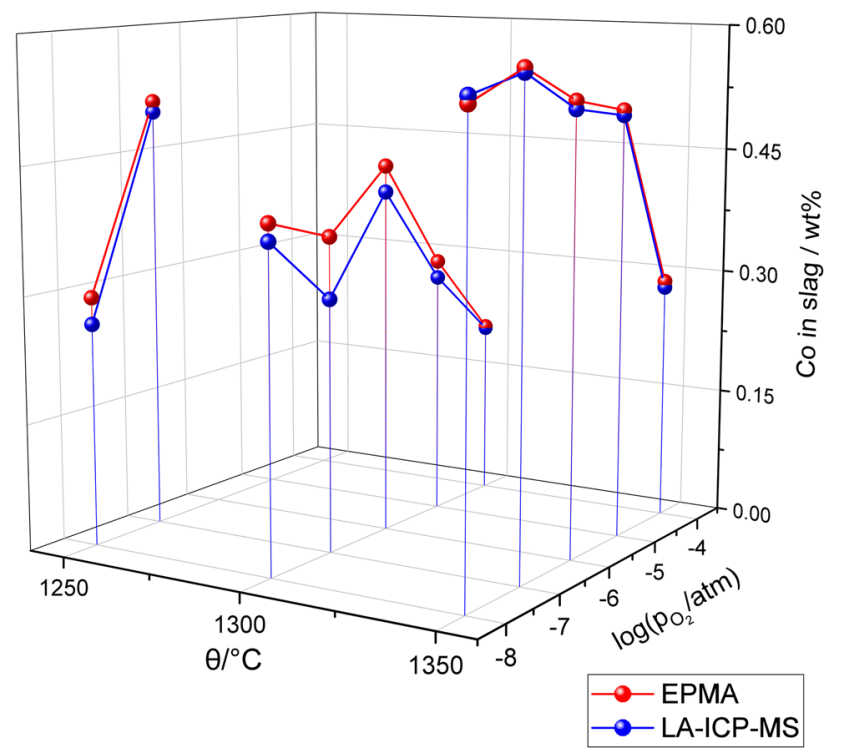

Fig. 8-Equilibrium concentrations of Co measured in the slag as a function of temperature and oxygen partial pressure using different analytic techniques.

acquired. The discrepancy at higher concentrations was most likely related to the fact that the concentrations measured are one or even two orders of magnitude higher than in the standard reference material utilized in the laser ablation method. In this case, the standard NIST 612 SRM contains Ni and Co only around 36 to 39 ppmw $^{[36]}$ and the extrapolation to the higher concentrations eventually caused the observed systematic errors.

Summarizing the above, the distribution coefficients of PMs and PGMs were calculated based on the LA-ICP-MS data for the slag and EPMA data for the metallic copper. The distribution coefficients for $\mathrm{Ni}$ and $\mathrm{Co}$, as well as for $\mathrm{Fe}$ and $\mathrm{Cu}$ were calculated based on the obtained EPMA data for both phases. 


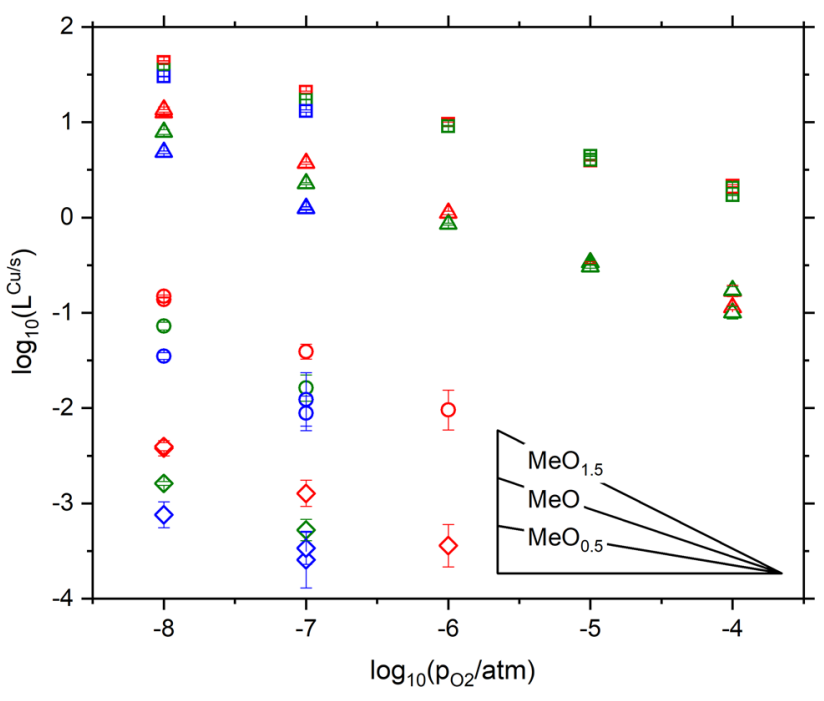

Fig. 9-Distribution coefficients of $\mathrm{Fe}(\diamond)$, Co $(\bigcirc), \mathrm{Ni}(\triangle)$, and $\mathrm{Cu}$ $(\square)$ as a function of oxygen partial pressure at various temperatures (red 1350; green 1300; blue $1250^{\circ} \mathrm{C}$ ) (Color figure online).

\section{Distribution of the Metals Between Copper Alloy and Slag}

When an element Me is dissolved in two immiscible liquids, it distributes between them. In equilibrium, the distribution of Me between molten copper and slag can be described by chemical reaction [1]:

$$
[\mathrm{Me}]+\frac{v}{2} \mathrm{O}_{2}=\left(\mathrm{MeO}_{v}\right),
$$

where parentheses [ ] and ( ) denote the metallic copper and the slag phases, respectively. The oxidation degree of $\mathrm{Me}$ in the slag is $2 v$. Under the equilibrium conditions, the equilibrium constant $K$ for reaction [1] is expressed as follows:

$$
K=\frac{a_{\mathrm{MeO}_{v}}}{a_{\mathrm{Me}} p_{\mathrm{O}_{2}}^{v / 2}},
$$

where $p_{\mathrm{O}_{2}}$ is the oxygen partial pressure, $a_{\mathrm{MeO}_{\mathrm{v}}}$ and $a_{\mathrm{Me}}$ are the activities of $\mathrm{MeO}_{v}$ and $\mathrm{Me}$, respectively.

The distribution coefficient of Me between copper alloy ('Cu') and slag ('s') $\mathrm{L}_{\mathrm{Me}}^{\mathrm{Cu} / \mathrm{s}}$ is the ratio of weight concentrations of Me dissolved in the phases in equilibrium. Furthermore, by utilizing expression [2], a relationship between the distribution coefficient and the oxygen partial pressure, as well as the Raoultian activity coefficients $\gamma$ of $\mathrm{Me}$ and $\mathrm{MeO}_{v}$ in molten copper and slag, respectively, can be derived ${ }^{[17,46]}$ :

$$
\mathrm{L}_{\mathrm{Me}}^{\mathrm{Cu} / \mathrm{s}}=\frac{[\text { wt pct Me }]}{(\text { wt pct Me })}=\frac{\left(\gamma_{\mathrm{MeO}_{v}}\right)\left[n_{\mathrm{T}}\right]}{K\left[\gamma_{\mathrm{Me}}\right]\left(n_{\mathrm{T}}\right)} p_{\mathrm{O}_{2}}^{-v / 2},
$$

where $n_{\mathrm{T}}$ denotes the total number of moles of constituents in $100 \mathrm{~g}$ of the respective phase.

Therefore, the distribution coefficient $\mathrm{L}_{\mathrm{Me}}^{\mathrm{Cu} / \mathrm{s}}$ can also be determined from Gibbs energy change of reaction [1] and the thermodynamic properties of element $\mathrm{Me}$ and its oxide $\mathrm{MeO}_{v}$ in molten copper and slag, respectively.

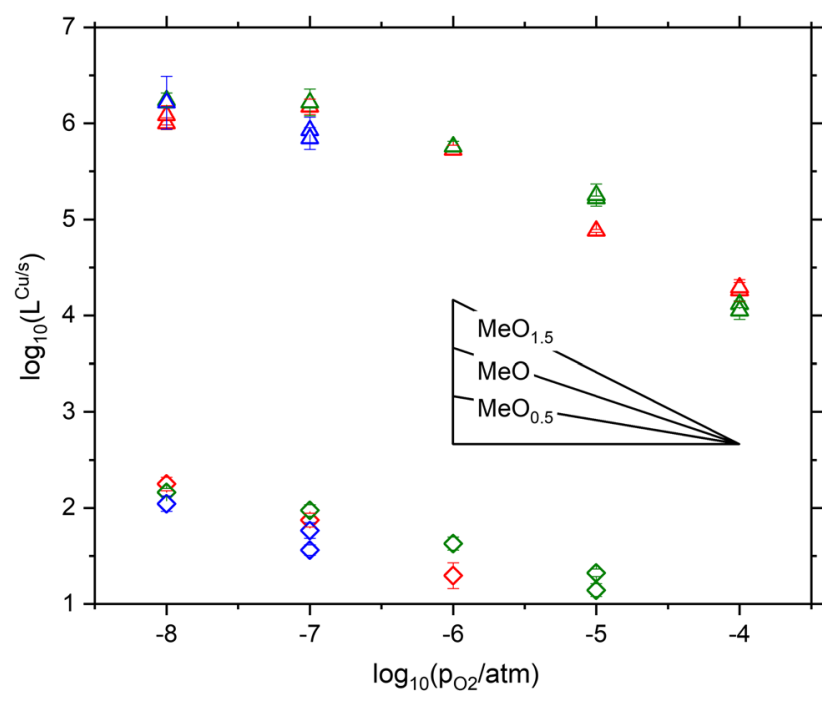

Fig. 10-Distribution coefficients of $\mathrm{Ag}(\diamond)$ and $\mathrm{Au}(\triangle)$ as a function of oxygen partial pressure at various temperatures (red 1350; green 1300; blue $1250^{\circ} \mathrm{C}$ ) (Color figure online).

The oxidation degree of $\mathrm{Me}$ in the slag can be determined from logarithmic form of expression [3]:

$$
\log _{10} \mathrm{~L}_{\mathrm{Me}}^{\mathrm{Cu} / \mathrm{s}}=\log _{10} \frac{\left(\gamma_{\mathrm{MeO}_{\mathrm{v}}}\right)\left[n_{\mathrm{T}}\right]}{K\left[\gamma_{\mathrm{Me}}\right]\left(n_{\mathrm{T}}\right)}-\frac{v}{2} \log _{10} p_{\mathrm{O}_{2}} .
$$

Equation [4] is a linear relation, where $\log _{10} \frac{\left(\gamma_{\mathrm{MeO}_{\mathrm{O}}}\right)\left[n_{\mathrm{T}}\right]}{K\left[\gamma_{\mathrm{Me}}\left(n_{\mathrm{T}}\right)\right.}$ is the intercept and $-\frac{v}{2}$ is the slope. The intercept is a constant value because the activity coefficients are constant, assuming that metallic species in copper alloy and oxide species in the slag follow Henrian behavior, while $n_{\mathrm{T}}$ values are nearly constant within a wide oxygen partial pressure range. Also the interactions between the minor solute species can be neglected due to their small concentrations.

The distribution coefficients of the minor solute metals (as well as $\mathrm{Fe}$ and $\mathrm{Cu}$ ) between copper alloy and slag were calculated with Eq. [5], while the respective standard uncertainties given as error bars were calculated using Eq. [6]:

$$
\begin{gathered}
\mathrm{L}_{\mathrm{Me}}^{\mathrm{Cu} / \mathrm{s}}=\frac{\overline{[\text { wt pct Me] }}}{\overline{\text { [wt pct Me }]}} \\
\Delta \mathrm{L}_{\mathrm{Me}}^{\mathrm{Cu} / \mathrm{s}}=\mathrm{L}_{\mathrm{Me}}^{\mathrm{Cu} / \mathrm{s}}\left\{\frac{\Delta[\text { wt pct Me }]}{\overline{[\text { wt pct Me }]}}+\frac{\Delta(\text { wt pct Me })}{\overline{\text { (wt pct Me })}}\right\},
\end{gathered}
$$

where wt pct Me is an average out of eight concentration measurements and $\Delta \mathrm{wt}$ pct $\mathrm{Me}$ is the standard deviation for [copper alloy] and (slag) phases, respectively.

Oxygen partial pressure severely affected the distributions of nickel and cobalt, as well as those of copper and iron. The obtained temperature dependence of $\mathrm{L}_{\mathrm{Me}}^{\mathrm{Cu} / \mathrm{s}}$ was less prominent for copper, compared to nickel, cobalt, and iron. However, the trend of increasing $\mathrm{L}_{\mathrm{Me}}^{\mathrm{Cu} / \mathrm{s}}$ with the increasing temperature was the same for all 


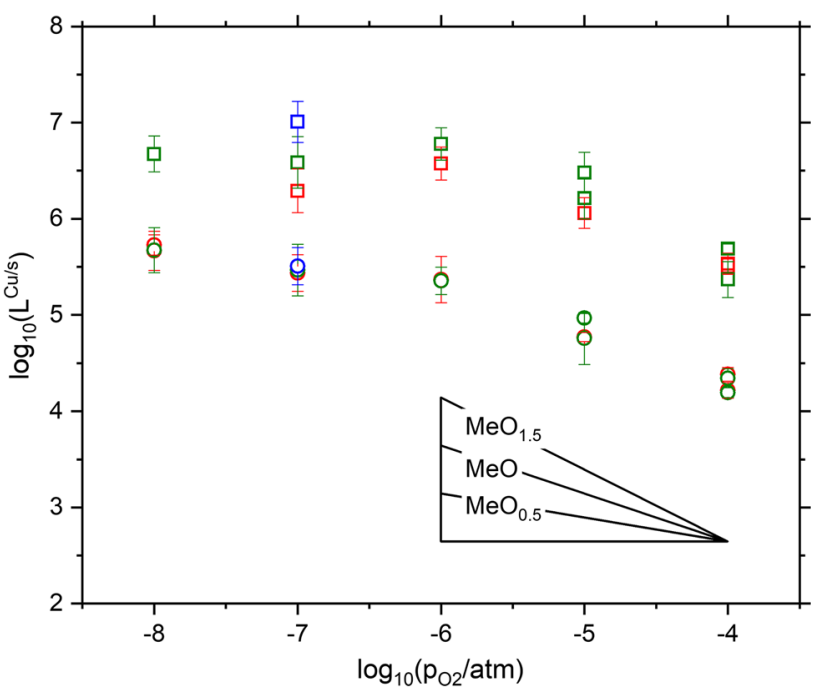

Fig. 11-Distribution coefficients of $\mathrm{Pd}(\bigcirc)$ and $\mathrm{Pt}(\square)$ as a function of oxygen partial pressure at various temperatures (red 1350; green 1300; blue $1250{ }^{\circ} \mathrm{C}$ ) (Color figure online).

four metals, as shown in Figure 9. The best-fit equations (Eqs. [7] through [10]) calculated from the experimental data of this study describe the partitioning of $\mathrm{Ni}, \mathrm{Co}$, $\mathrm{Fe}$, and $\mathrm{Cu}$ as a function of temperature $\left(\theta /{ }^{\circ} \mathrm{C}\right)$ and oxygen partial pressure. An extrapolation beyond the experimental range studied should be done with caution, taking into account the magnetite primary phase field in the lower temperature range and at higher oxygen partial pressures (see Figure 3).

$$
\begin{aligned}
\log _{10} \mathrm{~L}_{\mathrm{Cu}}^{\mathrm{Cu} / \mathrm{s}}= & 1.414 \times 10^{-3} \times\left(\frac{\theta}{{ }^{\circ} \mathrm{C}}\right)-0.323 \\
& \times \log _{10}\left(\frac{p_{\mathrm{O}_{2}}}{\mathrm{~atm}}\right)-2.871 \\
\log _{10} \mathrm{~L}_{\mathrm{Ni}}^{\mathrm{Cu} / \mathrm{s}}= & 3.864 \times 10^{-3} \times\left(\frac{\theta}{{ }^{\circ} \mathrm{C}}\right)-0.462 \\
& \times \log _{10}\left(\frac{p_{\mathrm{O}_{2}}}{\mathrm{~atm}}\right)-7.868 \\
\log _{10} \mathrm{~L}_{\mathrm{Co}}^{\mathrm{Cu} / \mathrm{s}}= & 5.782 \times 10^{-3} \times\left(\frac{\theta}{{ }^{\circ} \mathrm{C}}\right)-0.581 \\
& \times \log _{10}\left(\frac{p_{\mathrm{O}_{2}}}{\mathrm{~atm}}\right)-13.304 \\
\log _{10} \mathrm{~L}_{\mathrm{Fe}}^{\mathrm{Cu} / \mathrm{s}}= & 6.470 \times 10^{-3} \times\left(\frac{\theta}{{ }^{\circ} \mathrm{C}}\right)-0.489 \\
& \times \log _{10}\left(\frac{p_{\mathrm{O}_{2}}}{\mathrm{~atm}}\right)-15.079 .
\end{aligned}
$$

The distribution ratio of copper ranged from 43 to 2 , decreasing with the increasing oxygen partial pressure. The slope of the trend line was approximately 0.3 , similar to our previous study. ${ }^{[47]}$

Under reducing conditions, nickel concentration in the metal was about ten times higher than that in the slag, but under the oxidizing conditions, the situation was opposite. Nickel distributed rather evenly at the oxygen partial pressure around $10^{-6} \mathrm{~atm}$. The slope of the trend line was approximately 0.5 .

Equilibrium concentrations of cobalt and iron in the copper alloy diminished with the increasing oxygen partial pressure and with decreasing temperature. Eventually, they decreased at $p_{\mathrm{O}_{2}} \approx 10^{-6}$ atm down to the levels of the EPMA detection limit (Table IV). The slopes of the trend lines for these elements were about the same as for nickel.

Under the most oxidizing conditions of this study, representing the anode furnace processing or fire refining, copper concentration in slag was high, and the slag had therefore a higher basicity. ${ }^{[48]}$ Thus, the distribution coefficients under these conditions followed the trends less consistently. Under the copper fire-refining conditions, it was also clear that cobalt, iron, and nickel maintain so strong interactions with oxygen that they generated solubility minima. This is valid for solute metal at small concentrations and for dissolved oxygen at high solute metal concentrations. ${ }^{[49-51]}$ This phenomenon explains the behavior of cobalt distribution coefficient at high oxygen activities, Figures 8 and 9.

The equilibrium concentration of silver in the slag was 100 to 200 times lower than that in the metal under the reducing conditions $\left(p_{\mathrm{O}_{2}}=10^{-8} \mathrm{~atm}\right)$. Its distribution coefficient $\mathrm{L}_{\mathrm{Ag}}^{\mathrm{Cu} / \mathrm{s}}$ seemingly increased with rising temperature. The slope of the $\mathrm{L}_{\mathrm{Ag}}^{\mathrm{Cu}}$ trend line as a function of $p_{\mathrm{O}_{2}}$ at $1300{ }^{\circ} \mathrm{C}$ (Figure 10), omitting the highest oxygen partial pressure values where its concentration in the copper alloy was below the detection limit of EPMA, was about 0.3 .

The LA-ICP-MS detection limits of 1 to $10 \mathrm{ppbw}$ $\left(10^{-7}\right.$ to $\left.10^{-6} \mathrm{wt} \mathrm{pct}\right)$ for the noble metals in the slag (see Table V) and the concentrations of around $1 \mathrm{wt}$ pct for the solute elements in the copper alloy explain well the obtained scatter of the distribution coefficient values at low oxygen pressures, on the distribution coefficient level $10^{6}$ and higher (see Figures 10 and 11). Furthermore, in the case of silver, its vaporization rate increased significantly with the increasing temperature and oxygen partial pressure. The acceleration of silver vaporization at higher $p_{\mathrm{O}_{2}}$ is likely related to its higher equilibrium concentration (as $\mathrm{AgO}_{0.5}$ ) in the slag under more oxidizing conditions and a better exposure of the slag to the gas phase compared to metal alloy. 
The distribution coefficient of gold was scattered under reducing conditions of $p_{\mathrm{O}_{2}}<10^{-6}$ atm where its value was on the level of $10^{6}$, while at higher oxygen partial pressures, its solubility in the slag increased noticeably (Figure 10). The limiting slope of the distribution coefficient for gold at high oxygen pressures of $p_{\mathrm{O}_{2}}>10^{-6}$ atm was between 0.5 and 0.75 . The PGMs demonstrated trends similar to gold. It is evident that under reducing conditions, the distribution coefficient values of $\mathrm{Pd}$ were scattered on the level below $10^{6}$, while the values of $\mathrm{Pt}$ were larger than $10^{6}$ (see Figure 11). The 'limiting' slopes of $\mathrm{Pt}$ and $\mathrm{Pd}$ at high oxygen pressures $p_{\mathrm{O}_{2}}>10^{-6}$ atm were close to 0.5 .

The obtained solubilities of PMs and PGMs in the slag were in agreement with recent geochemical data, ${ }^{[28]}$ but are orders of magnitude smaller than suggested by various authors from metallurgical slags. ${ }^{[18,26,52]}$ This is most probably due to mechanical entrainment of metal in the slag which is difficult to detect and remove prior to the bulk analysis of the phases, and may be traced by direct microstructure observations only.

Based on the measured distribution coefficients and the determined slopes of the trend lines, the predominant oxide species of cobalt and nickel in the slag are $\mathrm{CoO}$ and $\mathrm{NiO}$. Although $\mathrm{Fe}$ and in particular $\mathrm{Cu}$ are not minor elements, the slopes of their trend lines suggest that their prevailing oxidation degrees in the slag are $2+$ $(\mathrm{FeO})$ and $1+\left(\mathrm{CuO}_{0.5}\right)$, respectively. The findings comply well with previous observations. ${ }^{[17,20,47,53-55]}$

Among the noble metals, silver most likely dissolved in the slag as $\mathrm{AgO}_{0.5}$, based on the present oxygen pressure slope of its $\log \mathrm{L}_{\mathrm{Ag}}^{\mathrm{Cu}}$ trend line. Regarding $\mathrm{Au}$, $\mathrm{Pd}$, and $\mathrm{Pt}$, the understanding of their dissolution mechanisms is still limited. However, their solubilities measured in the silica-saturated $\mathrm{Fe}-\mathrm{O}-\mathrm{SiO}_{2}$ slags and the distribution coefficients determined under the oxidizing conditions rule out the possibility of a predominant existence of metallic $\mathrm{Au}, \mathrm{Pt}$, and $\mathrm{Pd}$ species in the slag. At high oxygen partial pressures $p_{\mathrm{O}_{2}}>10^{-6} \mathrm{~atm}$, the slopes of the distribution coefficient trend lines vs $\log p_{\mathrm{O}_{2}}$ suggest oxidation degrees of $\mathrm{MeO}$ for $\mathrm{Pt}$ and $\mathrm{Pd}$ (see Figure 11), and between $\mathrm{AuO}$ and $\mathrm{AuO}_{1.5}$ for $\mathrm{Au}$ (Figure 10). The observations are in good agreement with recent findings in the literature. ${ }^{[28,29,32]}$

Among the studied metals, a pronounced trend was observed for copper (see Figure 9) and for those elements which are less noble than copper ( $\mathrm{Ni}, \mathrm{Co}$, and $\mathrm{Fe}$ ). Their distribution coefficients $\left(\mathrm{L}_{\mathrm{Me}}^{\mathrm{Cu} / \mathrm{s}}\right)$ rise with increasing temperature. The temperature dependencies of the distribution coefficients of the elements correlate to the enthalpy of formation of the respective metal oxide species. ${ }^{[7]}$ i.e., those elements having a large valence and a strong attraction for oxygen represent large enthalpies of formation for their oxides and consequently stronger temperature dependencies of the distribution coefficients (Figure 9). The temperature dependencies of noble metals (PMs and PGMs) were less prominent, probably influenced by analytical uncertainties in their large numerical values, i.e., the extremely low concentrations of these metals in the slag.

\section{CONCLUSIONS}

A comprehensive review of fundamentals, ${ }^{[56]}$ regarding phase equilibria and thermodynamics of the $\mathrm{Cu}-\mathrm{Fe}-\mathrm{O}-\mathrm{S}-\mathrm{SiO}_{2}$ quinary system, reported data available by the time. Its sulfur-oxygen potential diagrams were constructed by Yazawa ${ }^{[57]}$ Since then, a continuous effort has been made to develop a comprehensive understanding of the quinary and its subsystems using investigations with experimental and computational tools. ${ }^{[58-62]}$ However, in copper making of today, besides the main components, various impurities are present in the feed materials. Furthermore, the processing challenges are mainly related to quality of the raw materials, i.e., their copper content, mineralogy, the presence of various impurities, and their concentrations. Apparently, "copper-making is a technique of minor element control; a quality copper results from a controlled elimination of minor elements in the course of smelting and electrorefining". ${ }^{[14]}$ Thus, today's great challenge is to improve simultaneous and efficient recovery of the valuable minor elements as byproducts.

The distribution equilibria of $\mathrm{Ni}, \mathrm{Co}, \mathrm{Ag}, \mathrm{Au}, \mathrm{Pt}$, and $\mathrm{Pd}$ between metallic copper alloys and silica-saturated $\mathrm{Fe}-\mathrm{O}-\mathrm{SiO}_{2}$ slags were investigated in this study experimentally from $1250{ }^{\circ} \mathrm{C}$ to $1350{ }^{\circ} \mathrm{C}$ and from $10^{-8}$ to $10^{-4}$ atm $p_{\mathrm{O}_{2}}$. An analytic methodology was developed for the analysis of major and trace elements in experimental products using in situ methods, key to measuring accurate distributions. The correlations determined for the distribution coefficients, oxygen partial pressure, and temperature, aided in revealing dissolution mechanisms of the trace metals in the slag. The measured distribution coefficients $\mathrm{L}_{\mathrm{Me}}^{\mathrm{Cu} / \mathrm{s}}$ could be arranged in the following order: $\mathrm{Pt}>\mathrm{Au}>\mathrm{Pd}>>\mathrm{Ag}>(\mathrm{Cu})>\mathrm{Ni}>$ $\mathrm{Co}>(\mathrm{Fe})$.

The distributions of $\mathrm{Ni}, \mathrm{Co}$, and $\mathrm{Ag}$ were found to be in good agreement with the most previous authors. ${ }^{[63]} \mathrm{It}$ was also confirmed that at high temperatures, more $\mathrm{Ni}$ and Co distributed to the copper metal. Gold and PGMs dissolved in $\mathrm{Fe}-\mathrm{O}-\mathrm{SiO}_{2}$ slags much less than reported earlier and chemical solubilities of about 10 ppbw at $p_{\mathrm{O}_{2}}=10^{-8}$ atm were obtained for $\mathrm{Au}, \mathrm{Pd}$, and $\mathrm{Pt}$ at $1300{ }^{\circ} \mathrm{C}$. It was also evident that the distribution mechanisms of $\mathrm{Au}$ and PGMs in the slag were based on oxidic dissolution in the slag, and their chemical solubilities in the slag under copper-converting and fire-refining conditions were grossly overestimated in most previous studies on metallurgical slags. The vaporization rate of $\mathrm{Ag}$, making reliable measurements of solubilities and distribution coefficients difficult, increased significantly above $1300{ }^{\circ} \mathrm{C}$, deporting silver to the gas phase as flue dust.

\section{ACKNOWLEDGMENTS}

Open access funding provided by Aalto University. The authors are indebted to the EIT-Raw Materials, Knowledge and Innovation Community (KIC), Boli- 
den Harjavalta (Finland), and Eramet (France) for the financial support and guidance of this study (Grant \# EIT/RAW MATERIALS/SGA2017/1). The EPMA studies were carried out by Mr. Lassi Pakkanen of the Geological Survey of Finland.

\section{OPEN ACCESS}

This article is distributed under the terms of the Creative Commons Attribution 4.0 International License (http://creativecommons.org/licenses/by/4.0/), which permits unrestricted use, distribution, and reproduction in any medium, provided you give appropriate credit to the original author(s) and the source, provide a link to the Creative Commons license, and indicate if changes were made.

\section{ELECTRONIC SUPPLEMENTARY MATERIAL}

The online version of this article (https://doi.org/10.10 07/s11663-019-01576-2) contains supplementary material, which is available to authorized users.

\section{REFERENCES}

1. M. Geissdoerfer, P. Savaget, N.M.P. Bocken, and E.J. Hultink: $J$. Clean. Prod., 2017, vol. 143, pp. 757-68.

2. J. Cui and L. Zhang: J. Hazard. Mater., 2008, vol. 158, pp. 228-56.

3. M. Ghodrat, M.A. Rhamdhani, G. Brooks, S. Masood, and G. Corder: J. Clean. Prod., 2016, vol. 126, pp. 178-90.

4. M. Ghodrat, M.A. Rhamdhani, A. Khaliq, G. Brooks, and B Samali: J. Mater. Cycles Waste Manag., 2018, vol. 20 (1), pp. 386401.

5. O. Forsén, J. Aromaa, and M. Lundström: Recycling, 2017, vol. 2 (4), p. 2040019.

6. J. Wood, S. Creedy, R. Matusewicz, and M.A. Reuter: in METPLANT 2011 Plant Design \& Operational Strategies, Publications of the Aust. IMM, Perth, 2011, pp. 460-67.

7. G.R.F. Alvear Flores, S. Nikolic, and P.J. Mackey: JOM, 2014 , vol. 66 (5), pp. 823-32.

8. R. Cayumil, R. Khanna, R. Rajarao, P.S. Mukherjee, and V. Sahajwalla: Waste Manag., 2016, vol. 57, pp. 121-30.

9. F. Cucchiella, I. D'Adamo, S.C.L. Koh, and P. Rosa: Renew. Sustain. Energy Rev., 2015, vol. 51, pp. 263-72.

10. F. Tesfaye, D. Lindberg, J. Hamuyuni, P. Taskinen, and L. Hupa: Miner. Eng., 2017, vol. 111, pp. 209-21.

11. Report on Critical Raw Materials and the Circular Economy. Commission Staff Working Document, 2018. http://ec.europa.eu/ docsroom/documents/27348. Accessed 12 June 2018.

12. K. Nakajima, O. Takeda, T. Miki, and T. Nagasaka: Mater. Trans., 2009, vol. 50 (3), pp. 453-60.

13. D. Sukhomlinov and P. Taskinen: in Proceedings EMC 2017, vol. 3, Leipzig, U. Waschki ed., DGBM, Germany, 2017, pp. 1029-38. ISBN: 978-3-940276-74-2.

14. M. Nagamori and P. Mackey: Metall. Trans. B, 1978, vol. 9 (4), pp. $567-79$.

15. P. Mackey, G. McKerrow, and P. Tarassoff: in 104th AIME Annual Meeting, New York, TMS Paper Selection \# A75-81, TMS-AIME, NY, 1975.

16. P.J. Mackey: Can. Metall. Q., 1982, vol. 21 (3), pp. 221-60.

17. Y. Takeda, S. Ishiwata, and A. Yazawa: Trans. JIM, 1983, vol. 24 (7), pp. $518-28$

18. K. Yamaguchi: in Proceedings EMC 2011, vol. 1, Düsseldorf, J. Harre and U. Waschki, eds., DGBM, Clausthal-Zellerfeld, Germany, 2011, pp. 171-79. ISBN 978-3-940276-36-0.
19. W. Nishijima and K. Yamaguchi: J. Jpn. Inst. Met. Mater., 2014, vol. 78 (7), pp. 267-73.

20. M. Kashima, M. Eguchi, and A. Yazawa: Trans. JIM, 1978, vol. 19 (3), pp. 152-58.

21. J. Taylor and J. Jeffes: Trans. Inst. Min. Metall. Sect. C, 1975, vol. 84 (1), pp. C18-24

22. R. Altman and H.H. Kellogg: Trans. Inst. Min. Metall. Sect. C, 1972, vol. 81, pp. C163-175.

23. J.M. Toguri and N.H. Santander: Metall. Trans., 1972, vol. 3 (2), pp. 586-88.

24. Y. Takeda and G. Roghani: in 1st Int. Conf. Process. Mater. Prop., Honolulu, USA, H. Henein and T. Oki, eds., TMS, Warrendale (PA), 1993, pp. 357-60.

25. T. Hidayat, A. Fallah-Mehrjardi, J. Chen, P. Hayes, and E. Jak: in: Proc. Copper 2016, Jpn Inst. Mining Metall., Tokyo, 2016, pp. 1332-45.

26. D.R. Swinbourne, S. Yan, and S. Salim: Miner. Process. Extr. Metall., 2005, vol. 114 (1), pp. 23-29.

27. K. Baba and K. Yamaguchi: J. MMIJ, 2013, vol. 129 (5), pp. 20812.

28. A. Borisov and H. Palme: Am. Miner., 2000, vol. 85 (8), pp. 166573.

29. W. Ertel, D. Dingwell, and P. Sylvester: Chem. Geol., 2008, vol. 248 , pp. 119-39.

30. V. Laurenz, R. Fonsaeca, C. Ballhaus, and P. Sylvester: Geochim. Cosmochim. Acta, 2010, vol. 74 (10), pp. 2989-98.

31. M.A.H. Shuva, M.A. Rhamdhani, G.A. Brooks, S. Masood, M.A. Reuter, and M. Firdaus: in 8th International Symposium on High-Temperature Metallurgical Processing, J.Y. Hwang et al., eds., The Minerals, Metals \& Materials Series. Springer, Cham, 2017, pp. 419-427.

32. K. Avarmaa, H. O'Brien, and P. Taskinen: in Advances in Molten Slags, Fluxes, and Salts: Proc. of the 10th International Conference on Molten Slags, Fluxes and Salts, R.G. Reddy, P. Chaubal, P.C. Pistorius, and U. Pal, eds., TMS/Wiley, 2016, pp. 193-202.

33. Y.K. Rao: Stoichiometry and Thermodynamics of Metallurgical Processes, Cambridge University Press, Cambridge, 1985.

34. H. Longerich: in Laser Ablation-ICP-MS in the Earth Sciences: Current Practices and Outstanding Issues, P. Sylvester, ed. Short Course Series \#40, Mineral. Assoc. Canada, Quebec, 2008, pp. $1-18$.

35. F. Molnár, A. Middleton, H. Stein, H. O’Brien, Y. Lahaye, H. Huhma, L. Pakkanen, and B. Johanson: Ore Geol. Rev., 2018, vol. 101 , pp. $936-59$.

36. K.P. Jochum, U. Weis, B. Stoll, D. Kuzmin, Q. Yang, I. Raczek, D.E. Jacob, A. Stracke, K. Birbaum, D.A. Frick, D. Günther, and J. Enzweiler: Geostand. Geoanal. Res., 2011, vol. 35 (4), pp. 397429.

37. W.L. Griffin, W.J. Powell, N.J. Pearson, and S.Y. O'Reilly: in Laser Ablation-ICP-MS in the Earth Sciences: Current Practices and Outstanding Issues, P. Sylvester, ed.. Short Course Series \#40, Mineral. Assoc. Canada, Quebec, 2008, pp. 308-11.

38. T.W. May and R.H. Wiedmeyer: Atom. Spectrosc., 1998, vol. 19 (5), pp. $150-55$.

39. P.J. Sylvester: in Laser-ablation in the Earth Sciences: Principles and Application, P.J. Sylvester, ed. Short Course Series \#40. Mineral. Assoc. Canada, Quebec, 2001, pp. 203-13.

40. D. Sukhomlinov, F. Tesfaye, N. Hellstén, D. Lindberg, and P. Taskinen: J. Solid State Electrochem., 2018, vol. 22 (4), pp. 95972.

41. A. Yazawa: Erzmetall, 1980, vol. 33 (7-8), pp. 377-82.

42. J. Gisby, P. Taskinen, J. Pihlasalo, Z. Li, M. Tyrer, J. Pearce, K. Avarmaa, P. Björklund, H. Davies, M. Korpi, S. Martin, L. Pesonen, and J. Robinson: Metall. Mater. Trans. B, 2017, vol. 48B (1), pp. 91-98.

43. N. Hellstén and P. Taskinen: CALPHAD, 2017, vol. 59, pp. 18288.

44. M.A.H. Shuva, M.A. Rhamdhani, G.A. Brooks, S. Masood, and M.A. Reuter: Metall. Mater. Trans. B, 2016, vol. 47B (5), pp. 2889-2903

45. R. Sridhar, J. Toguri, and S. Simenov: Metall. Mater. Trans. B, 1997, vol. 28B (2), pp. 191-200.

46. A. Yazawa and Y. Takeda: Trans. JIM, 1982, vol. 23 (6), pp. 32833. 
47. K. Avarmaa, S. Yliaho, and P. Taskinen: Waste Manag., 2018, vol. 71, pp. $400-10$.

48. V. Petkov, P.T. Jones, and B. Blanpain: World Metall., 2007, vol. 60 (4), pp. 255-64.

49. U. Kuxmann and J. Riecke: Erzmetall, 1972, vol. 25 (8), pp. 395-404.

50. U. Kuxmann and K. Geissler: Erzmetall, 1977, vol. 30 (8), pp. $317-25$.

51. U. Kuxmann and H. Meyer-Grünow: Erzmetall, 1982, vol. 35 (7-8), pp. 363-73.

52. K. Yamaguchi: in Proceedings of Copper 2010, Hamburg, vol. 3. DGBM, Clausthal-Zellerfeld, 2010, pp. 1287-95.

53. A. Yazawa, Y. Takeda, and S. Nakazawa: in $A d v$. Sulfide Smelting. Proc. Int. Sulfide Smelting Symp. Extr. Process Metall. Meet, H.Y. Sohn, D.B. George, and A.D. Zunkel, eds., Metall. Soc. AIME, Warrendale, PA, 1983, pp. 99-117.

54. K. Teague, D. Swinbourne, and S. Jahanshahi: Aust. IMM Proc., 1998, vol. 303 (1), pp. 1-6.

55. H. Henao, M. Hino, and K. Itagaki: Mater. Trans., 2001, vol. 42 (9), pp. 1959-66.
56. J.F. Elliott: Metall. Trans. B, 1975, vol. 7B (1), pp. 17-33.

57. A. Yazawa: Can. Metall. Q., 1974, vol. 13 (3), pp. 443-53.

58. M.I. Devia and M.A. Sanchez: Miner. Process. Extr. Metall., 2011, vol. 120 (3), pp. 177-90.

59. E. Jak, T. Hidayat, D. Shishin, P.J. Mackey, and P.C. Hayes: Miner. Process. Extr. Metall., 2019, vol. 128 (1-2), pp. 74107.

60. D. Shishin and S.A. Decterov: CALPHAD, 2012, vol. 38, pp. 5970 .

61. D. Shishin, T. Hidayat, E. Jak, and S.A. Decterov: CALPHAD, 2013, vol. 41, pp. 160-79.

62. L. Xia, Z. Liu, and P.A. Taskinen: J. Chem. Thermodyn., 2016, vol. 98, pp. 126-34.

63. C. Capobianco and A. Amelin: Geochim. Cosmochim. Acta, 1994, vol. 58 (1), pp. 125-40.

Publisher's Note Springer Nature remains neutral with regard to jurisdictional claims in published maps and institutional affiliations. 